\title{
Ash and fine-mode particle mass profiles from EARLINET- AERONET observations over central Europe after the eruptions of the Eyjafjallajökull volcano in 2010
}

\author{
A. Ansmann, ${ }^{1}$ M. Tesche,${ }^{1}$ P. Seifert, ${ }^{1}$ S. Groß ${ }^{2}$ V. Freudenthaler, ${ }^{2}$ A. Apituley, ${ }^{3}$ \\ K. M. Wilson, ${ }^{3}$ I. Serikov, ${ }^{4}$ H. Linné, ${ }^{4}$ B. Heinold,${ }^{5}$ A. Hiebsch, ${ }^{1}$ F. Schnell, ${ }^{2}$ J. Schmidt, ${ }^{1}$ \\ I. Mattis, ${ }^{1}$ U. Wandinger, ${ }^{1}$ and M. Wiegner ${ }^{2}$ \\ Received 29 December 2010; revised 21 March 2011; accepted 28 March 2011; published 21 June 2011.
}

[1] A combined lidar-photometer method that permits the retrieval of vertical profiles of ash and non-ash (fine-mode) particle mass concentrations is presented. By using a polarization lidar, the contributions of non-ash and ash particles to total particle backscattering and extinction are separated. Sun photometer measurements of the ratio of particle volume concentration to particle optical thickness (AOT) for fine and coarse mode are then used to convert the non-ash and ash extinction coefficients into respective fine-mode and ash particle mass concentrations. The method is applied to European Aerosol Research Lidar Network (EARLINET) and Aerosol Robotic Network (AERONET) Sun photometer observations of volcanic aerosol layers at Cabauw, Netherlands, and Hamburg, Munich, and Leipzig, Germany, after the strong eruptions of the Icelandic Eyjafjallajökull volcano in April and May 2010. A consistent picture in terms of photometer-derived fine- and coarse-mode AOTs and lidar-derived non-ash and ash extinction profiles is found. The good agreement between the fine- to coarse-mode AOT ratio and non-ash to ash AOT ratio ( $<10 \%$ difference) in several cases corroborates the usefulness of the new retrieval technique. The main phases of the evolution of the volcanic aerosol layers over central Europe from 16 April to 17 May 2010 are characterized in terms of optical properties and mass concentrations of fine fraction and ash particles. Maximum coarse-mode $500 \mathrm{~nm}$ AOTs were of the order of 1.0-1.2. Ash concentrations and column mass loads reached maximum values around $1500 \mu \mathrm{g} / \mathrm{m}^{3}$ and $1750 \mathrm{mg} / \mathrm{m}^{2}$, respectively, on 16-17 April 2010. In May 2010, the maximum ash loads were lower by at least $50 \%$. A critical aspect of the entire retrieval scheme is the high uncertainty in the mass-to-extinction conversion for fresh volcanic plumes with an unknown concentration of particles with radii $>15 \mu \mathrm{m}$.

Citation: Ansmann, A., et al. (2011), Ash and fine-mode particle mass profiles from EARLINET-AERONET observations over central Europe after the eruptions of the Eyjafjallajökull volcano in 2010, J. Geophys. Res., 116, D00U02,

doi:10.1029/2010JD015567.

\section{Introduction}

[2] The major eruptions of the Eyjafjallajökull volcano in southern Iceland in April and May 2010 provided an unprecedented opportunity to study the dispersion of dense volcanic aerosol plumes across Europe [Ansmann et al., 2010; Flentje et al., 2010; Schumann et al., 2011] and the impact of these volcanic aerosol layers on atmospheric

\footnotetext{
${ }^{1}$ Leibniz Institute for Tropospheric Research, Leipzig, Germany.

${ }^{2}$ Meteorological Institute, Ludwig-Maximilians-Universität, Munich, Germany.

${ }^{3}$ Royal Netherlands Meteorological Institute, De Bilt, Netherlands.

${ }^{4}$ Max Planck Institute for Meteorology, Hamburg, Germany.

${ }^{5}$ School of Earth and Environment, University of Leeds, Leeds, UK.

Copyright 2011 by the American Geophysical Union. 0148-0227/11/2010JD015567
}

processes. Besides ash particles large amounts of sulfur dioxide were emitted. In the troposphere sulfur dioxide is converted to sulfate particles within a few days [Graf et al., 1997]. Networks of lidars (European Aerosol Research Lidar Network, EARLINET) and Sun photometers (Aerosol Robotic Network, AERONET) monitored the distribution and evolution of the volcanic layers on a European scale. As a consequence of the eruptions, the air space over many parts of Europe was closed after 16 April 2010. Air traffic was disrupted over the European continent for almost one week.

[3] For a detailed investigation of the atmospheric effects and to support activities toward an improved ash forecast system, the development of methods which permit a heightresolved separation of the contribution of non-ash (mainly fine-mode sulfate particles of volcanic and anthropogenic 
origin) and ash particles to the observed aerosol load is of high importance. From the aviation point of view, a good (vertically resolved) knowledge of the ash mass concentration is required. Because of their low melting temperature and their sharp-edged shapes ash particles can severely damage the turbines and front windows of aircraft (for more details, see Schumann et al. [2011]). Regarding the atmospheric impact, the separation of non-ash (sulfate) and ash is necessary because the two aerosol types show rather different optical properties (light scattering and absorption characteristics) and constitute two different particle modes. Ash particles contribute to the coarse-mode fraction, whereas sulfate particles are comparably small and thus belong to the fine particle mode. Concerning the influence on atmospheric cloud properties and processes, ash particles are known to be favorable ice nuclei and thus may trigger ice formation at comparably high temperatures [Durant et al., 2008; Fornea et al., 2009; P. Seifert et al., Ice formation in ash-influenced clouds after the eruption of the Eyjafjallajökull volcano in April 2010, submitted to Journal of Geophysical Research, 2011]. In contrast, sulfate particles are favorable cloud condensation nuclei (for liquid drop formation) and may suppress ice formation.

[4] In this paper, a combined lidar-photometer approach is presented. It permits the separation of the optical effects caused by weakly light depolarizing fine-mode and strongly light depolarizing ash particles and, in the next step, the quantification of fine-fraction and ash mass concentrations as a function of height. A further separation of the volcanic fine-mode particles, which formed from the emitted $\mathrm{SO}_{2}$, and anthropogenic fine-mode aerosol pollution is not possible by means of this technique. The latter usually dominates over highly populated and industrialized regions such as central Europe [Wandinger et al., 2004; Spindler et al., 2010].

[5] There are several ways to estimate the mass concentrations of volcanic particles from a combination of different observations (passive and active remote sensing, airborne and ground-based in situ measurements of microphysical, chemical, and optical properties). Some of these attempts are already published [Ansmann et al., 2010; Gasteiger et al., 2011; Schumann et al., 2011]. The method presented here is attractive for several reasons. The approach is simple, robust, and makes use of quality-assured, widespread (continentalscale) observations performed in the framework of wellestablished networks for aerosol observations. Furthermore, the technique is based on optical measurements conducted at ambient conditions; that is, the optical effects of the entire size distribution of volcanic aerosol particles are observed. There is no bias introduced by cutoff effects (large particles are not sampled) caused by aerosol inlets used for in situ observations. Finally, lidar and photometer remote sensing data cover the entire troposphere. All volcanic layers, even the optically very thin ones, can be detected and considered in the analysis.

[6] The paper is organized as follows: In section 2, the instrumentation is briefly outlined. The method is described in detail in section 3. In section 4, the technique is applied to EARLINET lidar observations in Netherlands and Germany. Based on the EARLINET measurements in combination with AERONET observations at the four lidar stations, the development of the volcanic aerosol layers over central Europe and the atmospheric impact of the volcanic events observed in April and May 2010 are discussed. Section 5 summarizes the findings.

\section{Instrumentation}

\subsection{EARLINET Lidars}

[7] The EARLINET aerosol Raman/polarization lidars used in this study are operated at the Cabauw Experimental Site for Atmospheric Research (CESAR, $52.0^{\circ} \mathrm{N}, 4.9^{\circ} \mathrm{E}$, at sea level), $60 \mathrm{~km}$ south of Amsterdam in Netherlands, and at Hamburg $\left(53.6^{\circ} \mathrm{N}, 10.0^{\circ} \mathrm{E}, 25 \mathrm{~m}\right.$ above sea level, asl), Leipzig $\left(51.4^{\circ} \mathrm{N}, 12.4^{\circ} \mathrm{E}, 125 \mathrm{~m}\right.$ asl), and Maisach $\left(48.2^{\circ} \mathrm{N}\right.$, $11.3^{\circ} \mathrm{E}, 515 \mathrm{~m}$ height asl, $25 \mathrm{~km}$ northwest of Munich) in northern, central, and southern Germany, respectively [Mattis et al., 2004; Freudenthaler et al., 2009; Apituley et al., 2009; Pappalardo et al., 2010]. All systems provide height profiles of particle backscatter and extinction coefficients (by using the Raman lidar method [Ansmann et al., 1992]), the corresponding extinction-to-backscatter ratios (lidar ratios), and volume and particle depolarization ratios (linear depolarization ratio) at the wavelength of $532 \mathrm{~nm}$. At daytime, the elastic backscatter lidar method [Fernald, 1984] is predominantly used to determine particle backscatter coefficients.

[8] The particle depolarization ratio allows us to discriminate layers dominated by backscattering by spheres (e.g., liquid water drops, sulfate particles) and by nonspherical particles (e.g., mineral dust, ash, or hexagonal and irregularly shaped ice crystals [Sassen, 2005]). Spherical particles cause a rather low particle depolarization ratio (close to zero), whereas the depolarization ratio is in the range of $0.30-0.33$ for mineral dust [Freudenthaler et al., 2009], of 0.35-0.37 for volcanic ash [Ansmann et al., 2010; Groß et al., 2010; Wiegner et al., 2011], and 0.4-0.6 for ice crystals at $532 \mathrm{~nm}$.

[9] The uncertainties of the EARLINET products are extensively discussed [Ansmann et al., 1992; Ferrare et al., 1998; Schmid et al., 2009; Freudenthaler et al., 2009; Groß et al., 2011] and are of the order of $<5 \%$ (depolarization ratio), $5 \%-10 \%$ (backscatter coefficient), 5\%-20\% (extinction coefficient), and 10\%-30\% (lidar ratio) in the case of dense volcanic plumes. The Leipzig lidar data were used to characterize the volcanic aerosol layers in the upper troposphere and lower stratosphere during 2008 and 2009 [Mattis et al., 2010]. The origins of these layers were eruptions of different volcanoes on the Aleutian Islands, Kamchatka, Alaska, and on the Kuril Islands.

\subsection{AERONET Photometers}

[10] Cabauw, Hamburg, Leipzig, and Munich are AERONET stations [Holben et al., 1998]. The AERONET Sun photometers measure the aerosol optical thickness (AOT) from 340 to $1640 \mathrm{~nm}$ (Leipzig, 8 channels), from 340 to $1020 \mathrm{~nm}$ (Munich, Hamburg, 7 channels), and from 440 to $1020 \mathrm{~nm}$ (Cabauw, 4 channels) and perform sky radiance observations at several wavelengths. The uncertainty in the AOT values is $<0.03(340-440 \mathrm{~nm})$ and 0.02 (500-1640 nm) [Toledano et al., 2009]. The AERONET products (see AERONET Web page http://aeronet.gsfc.nasa. gov) include (1) spectral AOTs, (2) fine-mode and coarsemode AOT (500 and $532 \mathrm{~nm}$ ) denoted as $\tau_{\mathrm{f}}$ and $\tau_{\mathrm{c}}$, respectively, in the following, (3) corresponding Ångström exponents describing the AOT wavelength dependence, (4) 
Table 1. Input Parameters in the Fine-Mode/Ash Separation Retrieval $^{\mathrm{a}}$

\begin{tabular}{lc}
\hline \multicolumn{1}{c}{ Parameter } & Value \\
\hline Ash depolarization ratio $\delta_{\mathrm{a}}$ & $0.36 \pm 0.02$ \\
Non-ash depolarization ratio $\delta_{\text {na }}$ & $0.01 \pm 0.01$ \\
Ash lidar ratio $S_{\mathrm{a}}$ & $50 \pm 10 \mathrm{sr}$ \\
Non-ash lidar ratio $S_{\mathrm{na}}$ & $40-80 \mathrm{sr}$ \\
Ash mass density $\rho_{\mathrm{a}}$ & $2.6 \pm 0.6 \mathrm{~g} / \mathrm{cm}^{3}$ \\
Fine-mode mass density $\rho_{\mathrm{f}}$ & $1.5 \pm 0.3 \mathrm{~g} / \mathrm{cm}^{3}$ \\
Ash conversion factor $\overline{v_{\mathrm{c}} / \tau_{\mathrm{c}}} \overline{\text { Fine }} \overline{v_{\mathrm{f}} / \tau_{\mathrm{f}}}$ & $(0.605 \pm 0.1) \times 10^{-6} \mathrm{~m}$ \\
Fine-mode conversion factor & $(0.177 \pm 0.016) \times 10^{-6} \mathrm{~m}$ \\
\hline
\end{tabular}

${ }^{a}$ Typical ranges of values are given. Optical properties at $532 \mathrm{~nm}$ are considered.

volume size distribution for the vertical column, (5) finemode and coarse-mode-related volume concentrations $v_{\mathrm{f}}$ and $v_{\mathrm{c}}$, respectively, and (6) effective radii for the total size distribution and for the fine-mode and the coarse-mode fraction of the particle size distribution [O'Neill et al., 2003; Dubovik and King, 2000; Dubovik et al., 2006]. The column volume concentrations $v_{\mathrm{f}}$ and $v_{\mathrm{c}}$ (in $\mu \mathrm{m}^{3} / \mu \mathrm{m}^{2}$ ) describe the total volume (in $\mu \mathrm{m}^{3}$ ) of fine and coarse-mode particles, respectively, in the entire vertical atmospheric column with horizontal cross section of $1 \mathrm{~m}^{2}$ (or $10^{12} \mu \mathrm{m}^{2}$ ).

\section{Method}

\subsection{Separation of Fine-Mode and Ash Optical Properties}

[11] The retrieval of mass concentrations of fine-mode and ash particles is based on a two-step approach. In the first step, the method makes use of lidar observations of the particle backscatter coefficient and the linear particle depolarization ratio at $532 \mathrm{~nm}$ in order to separate the backscatter contributions of the weakly light depolarizing non-ash aerosol components from the contribution of strongly light depolarizing ash particles. This separation method is outlined in detail by Tesche et al. [2009].

[12] The ash-related backscatter coefficient $\beta_{\mathrm{a}}$ is obtained from the measured total particle backscatter coefficient $\beta_{\mathrm{t}}$ as [Tesche et al., 2009]

$$
\beta_{\mathrm{a}}=\beta_{\mathrm{t}} \frac{\left(\delta_{\mathrm{t}}-\delta_{\mathrm{na}}\right)\left(1+\delta_{\mathrm{a}}\right)}{\left(\delta_{\mathrm{a}}-\delta_{\mathrm{na}}\right)\left(1+\delta_{\mathrm{t}}\right)},
$$

where $\delta_{\mathrm{t}}, \delta_{\text {na }}$, and $\delta_{\mathrm{a}}$ are the observed particle depolarization ratio and the assumed non-ash and ash particle depolarization ratios, respectively. The non-ash particle backscatter coefficient $\beta_{\mathrm{na}}$ is given by $\beta_{\mathrm{t}}-\beta_{\mathrm{a}}$. Parameters which have to be known a priori to solve equation (1) are listed in Table 1. It is assumed that the non-ash particle fraction causes negligible depolarization $\left(\delta_{\text {na }}=0.01\right)$. In contrast, the depolarization ratio of volcanic ash is large with values around 0.35-0.37 [Ansmann et al., 2010; Groß et al., 2010].

[13] We assume a simple, externally mixed two-component aerosol when using this separation technique. Thus we ignore the potential impact of particle aging (e.g., partly coating of ash particles with sulfate and subsequent changes in the shape characteristics) on the particle depolarization ratio. From our long-term experience with Saharan dust we do not have any indication that aging effects smooth the edges of dust particles and cause a decrease in the particle depolarization ratio. Schumann et al. [2011] show photographs of coated volcanic ash particles which clearly retained their irregular nonspherical shape. Furthermore, we observed strong heterogeneous ice formation (via the contact freezing mechanism) in which ash particles ( 5 days after the emission) were involved (Seifert et al., submitted manuscript, 2011). These ash particles must be widely free of hygroscopic material to serve as efficient ice nuclei. Thus the coating effect on the depolarization measurement seems to be small. This is further corroborated by the fact that the aerosol-type separation technique (equation (1)) was successfully applied to separate profiles of backscatter and extinction coefficients of nonspherical Saharan dust particles from the ones for biomass-burning smoke (spherical particles) in the outflow region of mixed dust and smoke plumes west of Africa [Tesche et al., 2009, 2011]. Groß et al. [2011] separated the optical effects caused by marine particles (spherical particles) and Saharan dust in the dust-laden boundary layer over the tropical Atlantic west of Africa. The separation technique, which is similar to the approach presented earlier by Sugimoto et al. [2003], Shimizu et al. [2004], and Reichardt et al. [2004], was also successfully applied to aged Asian aerosol mixtures.

[14] A volcanic measurement example is shown in Figure 1. The full scene of the 17 April observations (timeheight display of the range-corrected $1064 \mathrm{~nm}$ signal) is presented by Gasteiger et al. [2011] (Figure 1). A pure, highly depolarizing ash layer was present over Maisach (near Munich) in the free troposphere from 1.7 to $2.7 \mathrm{~km}$ height above ground level (agl). In the residual layer, backscattering was almost entirely caused by weakly depolarizing spherical particles, i.e., by volcanic sulfate particles formed from the emitted $\mathrm{SO}_{2}$, by anthropogenic haze, and by other spherical particles.

[15] Uncertainties in the separation of the backscatter coefficients of spherical and nonspherical particles caused by uncertainties in the input parameters, as given in Table 1, are discussed by Tesche et al. [2009]. In Figure 1, the resulting overall relative uncertainty is $15 \%-20 \%$ for both the finemode and ash backscatter coefficients. In this error analysis, uncertainties in the total backscatter coefficient $\beta_{\mathrm{t}}$ (due to uncertainties in the retrieval input parameters and signal noise), uncertainties in the assumed input parameters $\delta_{\text {na }}$ and $\delta_{\mathrm{a}}$ for equation (1), and in the measured total particle depolarization ratio $\delta_{\mathrm{t}}$ (due to calibration uncertainties and signal noise) are considered.

\subsection{Retrieval of Fine-Mode and Ash Mass Concentrations}

[16] In the second step of the retrieval, the mass concentrations $m_{\mathrm{a}}$ and $m_{\mathrm{f}}$ of ash and fine-mode particles, respectively, are derived from the ash and non-ash backscatter coefficients $\beta_{\mathrm{a}}$ and $\beta_{\mathrm{na}}$ [Ansmann et al., 2010]:

$$
\begin{aligned}
& m_{\mathrm{a}}=\rho_{\mathrm{a}}\left(\overline{v_{\mathrm{c}} / \tau_{\mathrm{c}}}\right) \beta_{\mathrm{a}} S_{\mathrm{a}}, \\
& m_{\mathrm{f}}=\rho_{\mathrm{f}}\left(\overline{v_{\mathrm{f}} / \tau_{\mathrm{f}}}\right) \beta_{\mathrm{na}} S_{\mathrm{na}} .
\end{aligned}
$$

Here the fundamental assumption is made that the lidarderived non-ash fraction is identical to the photometerderived fine particle fraction and consequently that the 


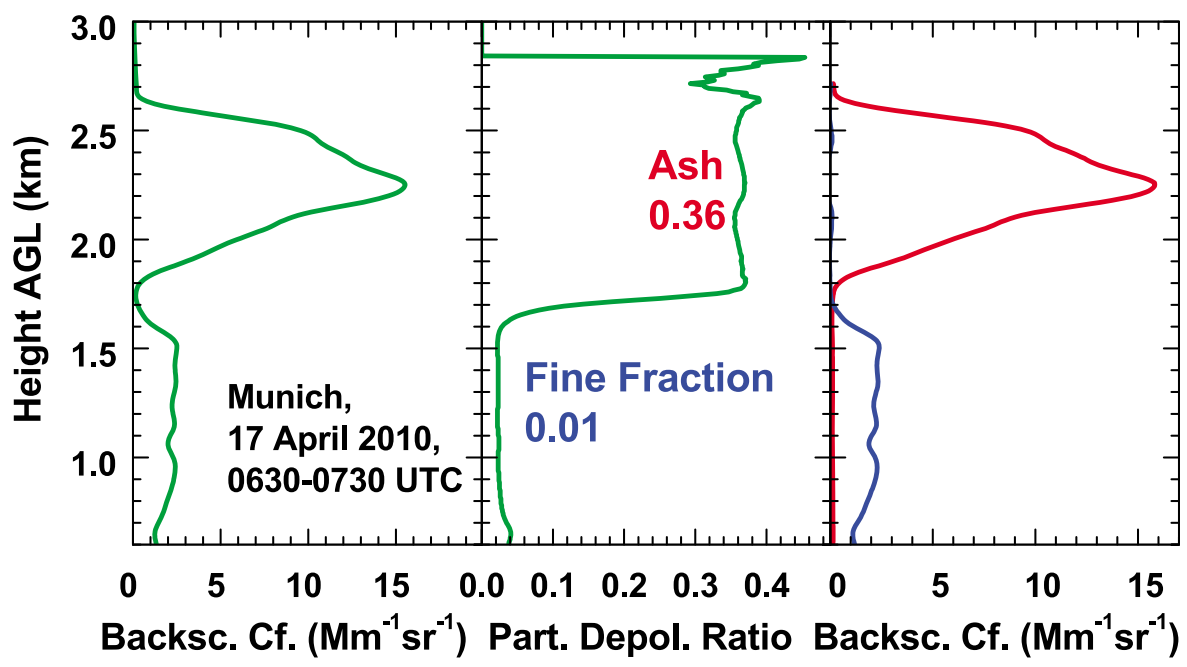

Figure 1. (left) The $532 \mathrm{~nm}$ particle backscatter coefficient, (middle) particle depolarization ratio, and (right) ash (red curve) and fine-mode particle backscatter coefficients (blue curve), computed by applying equation (1). The lidar observations were taken at Maisach (25 km northwest of Munich) on 17 April 2010, 0630-0730 UTC.

lidar-derived ash fraction is identical to the coarse particle fraction obtained from the photometer observations. The terms $\rho_{\mathrm{f}}$ and $\rho_{\mathrm{a}}$ in equations (2) and (3) are the assumed mass densities of fine-mode and ash particles, respectively. The terms $\overline{v_{\mathrm{c}} / \tau_{\mathrm{c}}}$ and $\overline{v_{\mathrm{f}} / \tau_{\mathrm{f}}}$ denote volume-to-extinction conversion factors for coarse mode and fine mode, respectively. The particle backscatter coefficient $\beta$ (for ash (a) or non-ash (na) particles) multiplied by the respective extinction-to-backscatter ratio $S$ yields the particle extinction coefficient (for ash and non-ash particles).

[17] Values of $\rho_{\mathrm{f}}$ around $1.5 \pm 0.3 \mathrm{~g} / \mathrm{cm}^{3}$ in Table 1 consider a variable liquid water content of the mostly sulfatecontaining particles (ammonium sulfate) as a function of relative humidity [Hess et al., 1998; Tang and Munkelwitz, 1994]. The density of ash particles $\rho_{\mathrm{a}}$ may range from 2 to $3 \mathrm{~g} / \mathrm{cm}^{3}$ and depends on the actual composition of the aerosol mixture (volcanic glass, minerals, and lithic fragments, http://volcanoes.usgs.gov/ash/properties.html) and the morphological properties of the ash particles.

[18] The extinction-to-backscatter ratio of the ash particles $S_{\mathrm{a}}$ at $532 \mathrm{~nm}$ is required to obtain the respective non-ash and ash particle extinction coefficients $\sigma_{\mathrm{a}}=\beta_{\mathrm{a}} S_{\mathrm{a}}$ and $\sigma_{\mathrm{na}}=$ $\beta_{\mathrm{na}} S_{\mathrm{na}}$. These extinction values are needed in the mass retrieval after equations (2) and (3). The basic lidar data analysis [Fernald, 1984; Ansmann et al., 1992] only delivers total backscatter coefficients $\beta_{\mathrm{t}}$ (at daytime, Fernald method) by assuming an appropriate lidar ratio $S_{\mathrm{t}}$ (e.g., obtained by means of daytime photometer observations) and backscatter and extinction coefficients and lidar ratio $\left(\beta_{\mathrm{t}}, \sigma_{\mathrm{t}}\right.$, and $\left.S_{\mathrm{t}}\right)$ at nighttime (Raman lidar method). To estimate the ash-related extinction coefficient $\sigma_{\mathrm{a}}=\beta_{\mathrm{a}} S_{\mathrm{a}}$ with $\beta_{\mathrm{a}}$ from equation (1) we use $S_{\mathrm{a}}=50 \mathrm{sr}$. The non-ash extinction coefficient $\sigma_{\text {na }}$ ( $=\beta_{\mathrm{na}} S_{\mathrm{na}}$ in equation (3)) is then obtained from $\sigma_{\mathrm{t}}-\sigma_{\mathrm{a}}$ (at nighttime) or $\beta_{\mathrm{t}} S_{\mathrm{t}}-\sigma_{\mathrm{a}}$ (at daytime). The range of lidar ratios for volcanic ash as well as for non-ash particles (sulfate, urban haze) are presented in Table 1 and are based on actual observations during the April-May 2010 period. Nighttime observations at Munich at around 0300 UTC on
17 April 2010 (several hours before the measurement shown in Figure 1) revealed, e.g., lidar ratios of $69 \pm 6 \mathrm{sr}$ for the non-ash aerosol in the residual layer below $1.5 \mathrm{~km}$ height and values around $49 \pm 4 \mathrm{sr}$ in the ash layer [Gro $\beta$ et al., 2010]. For aged, anthropogenic sulfate layers, lidar ratios are usually around 50-60 sr [Ackermann, 1998; Mattis et al., 2004].

[19] The volume-to-AOT ratios $\overline{v_{\mathrm{f}} / \tau_{\mathrm{f}}}$ and $\overline{v_{\mathrm{c}} / \tau_{\mathrm{c}}}$ in Table 1 are computed from the AERONET products $v_{\mathrm{f}}, v_{\mathrm{c}}, \tau_{\mathrm{f}}$, and $\tau_{\mathrm{c}}$. The products are explained in section 2.2 . Figure 2

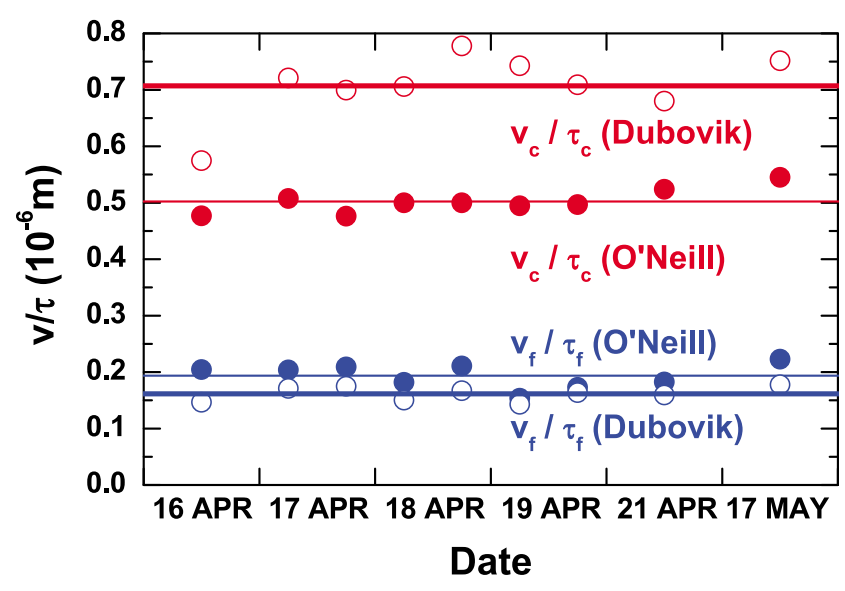

Figure 2. Ratio of volume concentration $v$ to aerosol optical thickness $\tau$ (at $532 \mathrm{~nm}$ ) for several days from 16 April to 17 May 2010. The horizontal lines indicate the mean values. The volume concentrations and optical thicknesses are computed from the Leipzig AERONET Sun photometer observations. The terms $v_{\mathrm{f}}$ and $v_{\mathrm{c}}$ denote fine-mode and coarse-mode volume concentration, respectively. Similarly, $\tau_{\mathrm{f}}$ and $\tau_{\mathrm{c}}$ denote fine-mode and coarse-mode particle optical thickness, respectively, computed after the Dubovik approach or the O'Neill method. See text for more details. 
shows individual values of the volume-to-AOT ratio for fine mode, $v_{\mathrm{f}} / \tau_{\mathrm{f}}$, and coarse mode, $v_{\mathrm{c}} / \tau_{\mathrm{c}}$, for the time period from 16 April to 21 April and for 17-18 May 2010. The values are carefully checked for cirrus interference. Furthermore, only cases with a fine-mode fraction (fine-mode AOT compared to total AOT) $<76 \%$ are considered. For fine-mode fractions $>80 \%$ the retrieval of coarse-mode volume concentration and AOT is no longer reliable because of the small impact of the coarse-mode particles on the measured optical effects. Only $1-2$ representative values per day are shown in Figure 2. Much more observations of the volume-to-AOT ratios are available for sunny days such as during the period from 17 to 19 April.

[20] Figure 2 shows two different sets of $v / \tau$ ratio for both the fine and the coarse particle modes. Both sets are based on the same $v_{\mathrm{f}}$ and $v_{\mathrm{c}}$ values. These are obtained in the following way: In the first step, the combined photometry and sky radiometry data are used to obtain the columnintegrated volume size distribution by applying the inversion scheme after Dubovik and King [2000] and Dubovik et al. [2006]. In the next step, the algorithm searches for the minimum in the bimodal volume size distribution. The part of the size distribution that is left of the minimum defines the fine-mode fraction $v_{\mathrm{f}}$ and the right part of the size distribution yields the coarse-mode fraction $v_{\mathrm{c}}$.

[21] The AERONET database contains two sets of AOTs for each mode. One set of fine- and coarse-mode AOTs $\tau_{\mathrm{f}}$ and $\tau_{\mathrm{c}}$ is computed from the observed total particle AOTs with the spectral curvature algorithm developed by O'Neill et al. [2003] and described in detail in that paper. The second set uses the AOT values that are directly related to the segments of the volume size distribution from which $v_{\mathrm{f}}$ and $v_{\mathrm{c}}$ are computed [Dubovik and King, 2000; Dubovik et al., 2006]. In this so-called Dubovik approach, the fineand coarse-mode optical depths $\tau_{\mathrm{f}}$ and $\tau_{\mathrm{c}}$ are computed at 440 and $675 \mathrm{~nm}$ (and provided by the AERONET database) so that the fine-mode and coarse-mode AOTs at $532 \mathrm{~nm}$ have to be obtained by means of respective $440-675 \mathrm{~nm}$ Ångström exponents. The O'Neill and Dubovik AOTs are given for slightly different times (30-90 s difference).

[22] O'Neill et al. [2003] present an extended error analysis and discuss the differences (systematic bias) between the fine-mode and coarse-mode AOTs obtained with the spectral curvature algorithm and the direct computation for $v_{\mathrm{f}}$ and $v_{\mathrm{c}}$. As explained in detail by O'Neill et al. [2003], the Dubovik approach overestimates the coarse-mode AOT $\tau_{\mathrm{c}}$ and thus underestimates the fine-mode AOT $\tau_{\mathrm{f}}$. On the other hand, $\tau_{\mathrm{c}}$ after the O'Neill method can be regarded as a value that is frequently close to the lower limit of the possible $\tau_{\mathrm{c}}$ range. As a consequence, we interpret the resulting $v / \tau$ ratios in Figure 2 (Dubovik and O'Neill solutions) for each mode as the full range of values which are compatible with the basic AERONET observations. In equations (2) and (3), we thus simply use the mean value of the two horizontal lines for each mode in Figure 2. The horizontal lines represent values of $0.161 \times 10^{-6} \mathrm{~m}$ for fine mode and $0.707 \times 10^{-6} \mathrm{~m}$ for coarse mode (Dubovik approach) and $0.194 \times 10^{-6} \mathrm{~m}$ for fine mode and $0.502 \times 10^{-6} \mathrm{~m}$ for coarse mode $\left(\mathrm{O}^{\prime} \mathrm{Neill}\right.$ approach). The mean conversion factors $\overline{v_{\mathrm{f}} / \tau_{\mathrm{f}}}=0.177 \times$ $10^{-6} \mathrm{~m}$ and $\overline{v_{\mathrm{c}} / \tau_{\mathrm{c}}}=0.605 \times 10^{-6} \mathrm{~m}$ are given in Table 1 together with an uncertainty representing the range of possible values shown in Figure 2.
[23] It is noteworthy to mention that Barnaba and Gobbi [2004] computed the specific extinction coefficient $(1 /(\rho \overline{v / \tau})$ after equations (2) and (3)) at $532 \mathrm{~nm}$ for 20000 realistic combinations of particle number concentration, size distribution, and refractive index characteristics. According to this study, $v / \tau$ ratios for pure dust size distributions (dominated by coarse-mode particles) are $(0.5-0.83) \times 10^{-6} \mathrm{~m}$ for extinction coefficients of $100-300 \mathrm{Mm}^{-1}$ (an increasing extinction coefficient is indicative for an increasing mean or effective radius of the size distribution) and around $1 \times 10^{-6} \mathrm{~m}$ for extinction coefficients $>500 \mathrm{Mm}^{-1}$. For continental size distributions (urban haze, dominated by fine-mode particles) the $v / \tau$ ratios accumulate around $0.18 \times 10^{-6} \mathrm{~m}$ and were almost independent of the extinction coefficient.

[24] A significant source of uncertainty in the entire AERONET retrieval scheme remains to be discussed. The AERONET algorithm considers particles with radii up to $15 \mu \mathrm{m}$ only. Larger particles which are probably present in fresh volcanic plumes are neglected in the inversion method. This neglect can introduce a significant bias in the computation of the volume size distribution from the AERONET measurements [Müller et al., 2010] with the result of a large underestimation of the ash mass load from the lidar data by more than $100 \%$. In the presence of those large particles the coarse-mode volume-to-AOT conversion factor is much larger than the applied one of $0.605 \times 10^{-6} \mathrm{~m}$. This aspect is discussed in more detail in section 4.1. Further uncertainties in the retrieval of the volume size distribution originate from the unknown shape of the ash particles (and thus of the unknown scattering phase function). In the computation, the desert dust shape model (spheroid particles) is applied [Dubovik et al., 2006]. Gasteiger et al. [2011] discuss shape effects in the retrieval of microphysical properties of volcanic ash from optical (lidar) measurements.

[25] An example of the conversion of the lidar-derived ash and non-ash backscatter coefficients, $\beta_{\mathrm{a}}$ and $\beta_{\text {na }}$, into ash and non-ash (fine mode) particle mass concentrations $m_{\mathrm{a}}$ and $m_{\mathrm{f}}$, respectively, is shown in Figure 3. Fine-fraction and coarsefraction (ash) mass concentrations are estimated from the measured backscatter profiles in Figure 1 by applying equations (2) and (3) and by using the input parameters in Table 1. On 17 April 2010, the fine-mode-dominated layer (residual layer, $30-42 \mu \mathrm{g} / \mathrm{m}^{3}$ from 1.0 to $1.5 \mathrm{~km}$ height) and ash layer (lofted layer in the free troposphere, peak ash concentrations of more than $1300 \mu \mathrm{g} / \mathrm{m}^{3}$ after equation (2)) were clearly separated. The column ash load in the layer from $1.8-2.7 \mathrm{~km}$ was $615 \mathrm{mg} / \mathrm{m}^{2}$. Flentje et al. [2010] report particle mass concentration measurements at the Meteorological Observatory Hohenpeißenberg $(50 \mathrm{~km}$ south of the lidar site at Maisach) at $980 \mathrm{~m}$ height asl. On 17 April 2010, the particle mass concentration increased from $20 \mu \mathrm{g} / \mathrm{m}^{3}$ to $40 \mu \mathrm{g} / \mathrm{m}^{3}$ at the observatory around noon.

[26] The uncertainty in the mass concentration in Figure 3 is estimated to be about $40 \%$. The uncertainty is obtained by applying the law of error propagation to equations (2) and (3) and by considering the individual uncertainties in the non-ash and ash backscatter coefficients $(20 \%)$, in the volume-to-AOT ratio estimates $(15 \%)$, in the lidar ratios $(20 \%)$, and in the mass density estimates $(25 \%)$. The uncertainty in the density of ash particles is caused by the unknown morphological properties and the actual composition of the particle aggregates which may even vary with 


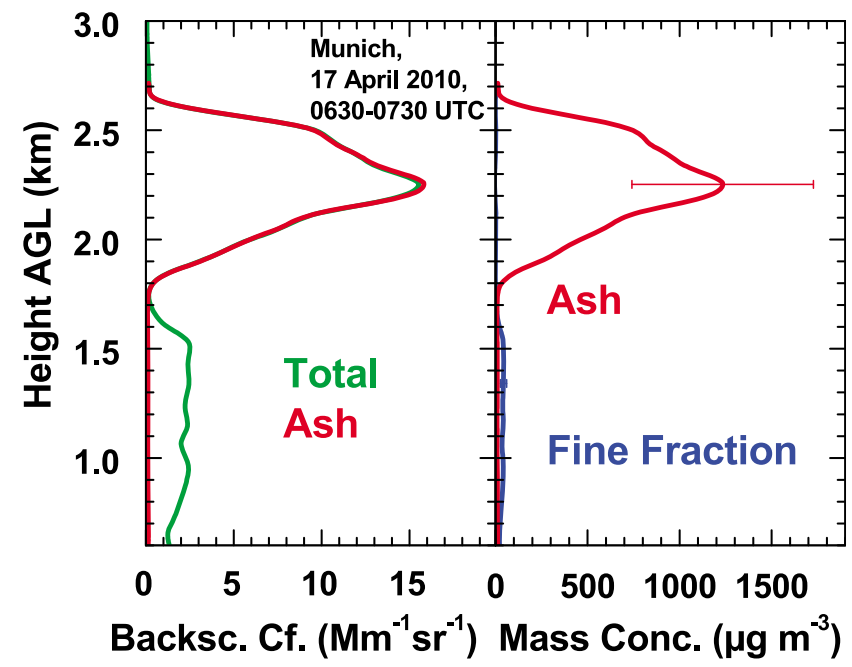

Figure 3. (left) The $532 \mathrm{~nm}$ total particle backscatter coefficient (green) and ash-related particle backscatter coefficient (red) and (right) fine-mode particle mass concentration (blue) and ash mass concentration (red). The mass concentrations are computed by means of equations (2) and (3) and the input parameters in Table 1. Error bars indicate the $40 \%$ uncertainty in the mass retrieval. height during an actual lidar measurement. The uncertainty in the fine-mode particle density results from the variable water content (as a function of the vertically varying relative humidity). The $15 \mu \mathrm{m}$ cutoff effect is not included in the error analysis and not considered in the error bars shown in section 4. Because the observations in Figure 3 were performed more than $50 \mathrm{~h}$ after the emission, a strong bias caused by ignoring particles with radii $>15 \mu \mathrm{m}$ in the AERONET inversions and in the extinction-to-mass conversion can be excluded.

\section{Observations}

[27] Four episodes of the April-May 2010 volcanic period are highlighted. Maps of ash-related AOT at $500 \mathrm{~nm}$ of these events are shown in Figure 4 as calculated with a regional transport model [Heinold et al., 2007, 2008]. Uncertainties in the AOT maps result from uncertain input parameters such as volcanic plume height, vertical distribution of emitted ash and gases, and wind fields [Heinold et al., 2011].

[28] The first phase of major eruptions of the Eyjafjallajökull volcano occurred on 14-15 April 2010. Volcanic ash plumes reached heights of 10-12 km asl [Stohl et al., 2011] and were advected toward central Europe within 1-2 days with a strong northwesterly air flow. A dense aerosol plume reached the
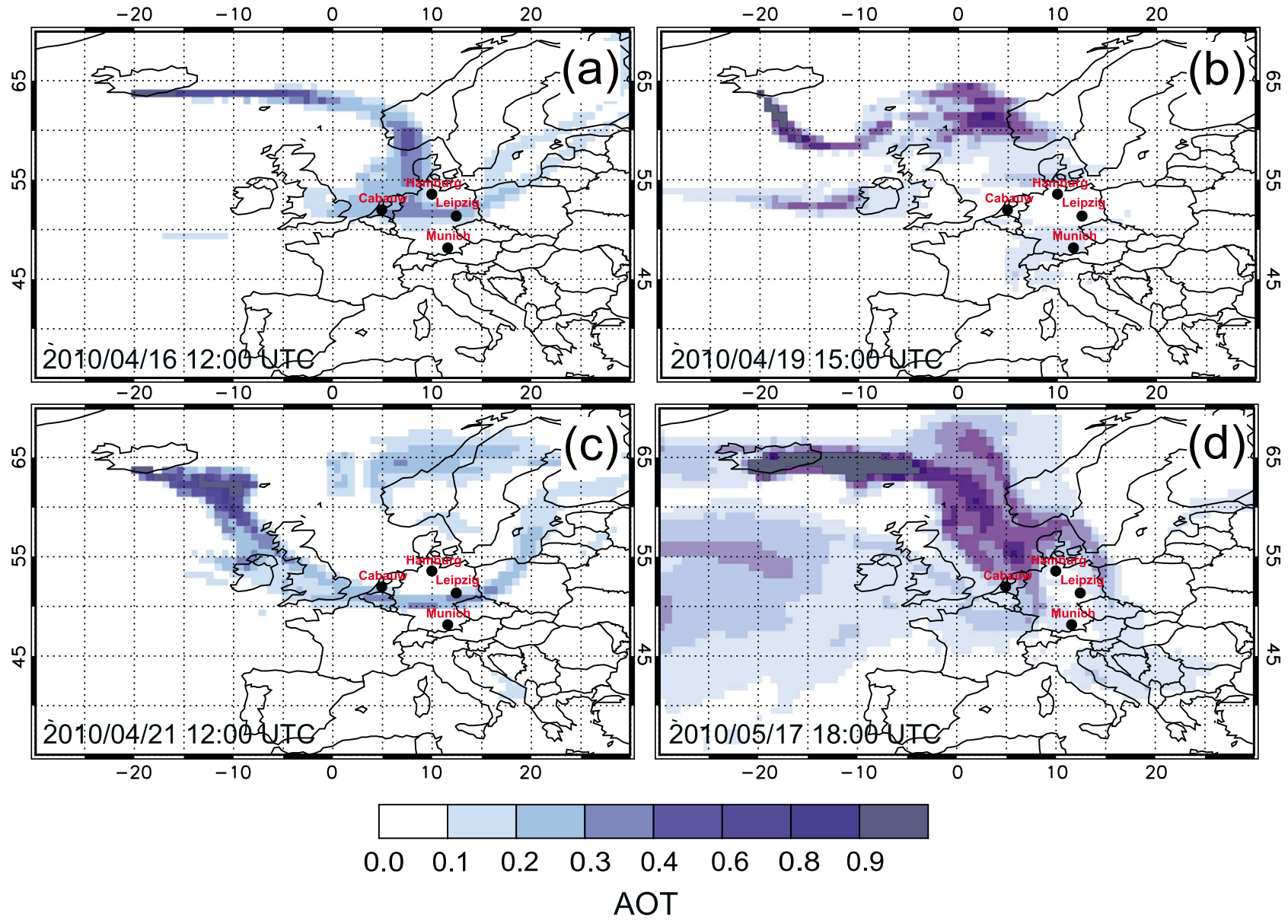

Figure 4. Ash-related $500 \mathrm{~nm}$ AOT for 16, 19, and 21 April 2010 and 17 May 2010 simulated with the regional atmospheric transport model COSMO-MUSCAT. 


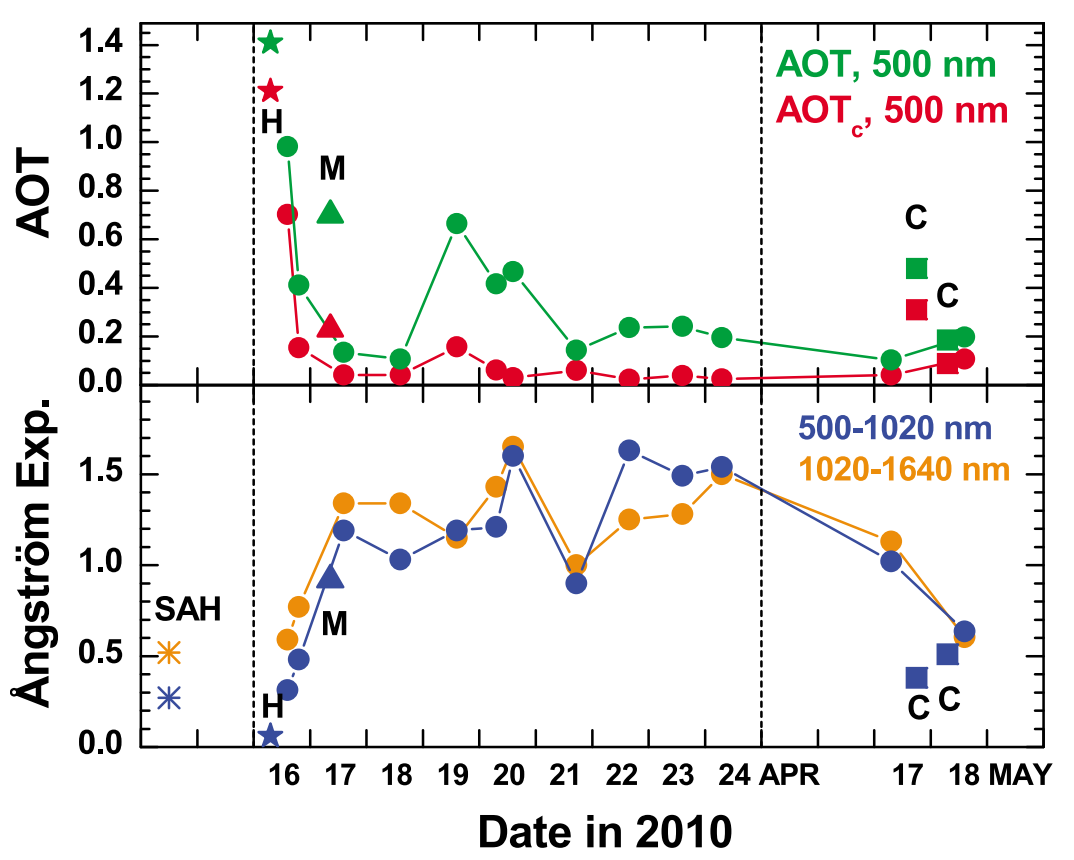

Figure 5. Total (green) and coarse-mode (red) $500 \mathrm{~nm}$ AOT and Ångström exponents computed from AOTs measured at 500 and $1020 \mathrm{~nm}$ (blue) and at 1020 and $1640 \mathrm{~nm}$ (orange) at Leipzig (circles). Individual values (carefully cloud screened by means of lidar and representative for several hours or even the entire day) show the significant changes in the optical properties with time. For comparison, Angström exponents for Saharan dust over Leipzig (SAH, stars to the left) are given in addition. A few AOTs and 500/1020 nm Ångström exponents for Hamburg (H, stars), Munich (M, triangles), and Cabauw (C, squares) are added.

European continent on 16 April 2010 (see Figure 4a). A part of this volcanic aerosol mass was advected to western Europe and remained there for 2 days. On 19-20 April 2010 these aged volcanic aerosol layers crossed the central and southern parts of Germany for a second time (Figure $4 b$ ).

[29] Fresh volcanic plumes emitted between 17 and 19 April 2010 reached central Europe between 21 and 24 April 2010 (Figure 4c). A new phase of volcanic activity started after 5 May 2010 [Stohl et al., 2011]. These eruptions intensified in mid-May. The emitted $\mathrm{SO}_{2}$ and ash plumes considerably affected central European aerosol conditions on 17-18 May 2010 (see Figure 4d). After 21 May 2010, the eruptive activity of the volcano weakened significantly.

\subsection{AERONET Observations}

[30] Before we discuss the lidar profiles of individual observations, we begin with an overview of the situation as observed with the AERONET Sun photometers. Figure 5 (top) shows the development of the aerosol load over central Europe in terms of the $500 \mathrm{~nm}$ AOT and the coarsemode AOT. In the April-May 2010 period, the Hamburg AERONET station reported the highest coarse-mode optical depths of up to 1.0-1.2 on 16 April 2010 (0630-0700 UTC). This event is discussed in section 4.2. The sharp ash front (with an horizontal extent of 200-250 km) reached Cabauw and Leipzig at around 1200 UTC on 16 April 2010. A maximum coarse-mode AOT of 0.7 was observed at Leipzig at around 1330 UTC. The ash clouds reached Munich and the Alps in the night of 16-17 April 2010 [Flentje et al., 2010; Groß et al., 2010]. Maximum coarse- mode AOTs of $0.2-0.25$ were observed at Munich around 0800 UTC on 17 April 2010, but fine-mode AOT exceeded 0.5 . Typical $500 \mathrm{~nm}$ AOT values range from 0.1 to 0.2 for northwesterly airflows at Munich during springtime. To obtain these typical (background) optical depths, we analyzed all AERONET observations at Munich during April of the years 2007-2009 and 2010 (first half of April). We computed backward trajectories $(850 \mathrm{hPa}$ level) for the respective 71 observations and selected five cases that showed the same airflow (characterized by very similar trajectories) as in the morning of 17 April 2010. The mean $500 \mathrm{~nm}$ AOT of these five cases is assumed to represent undisturbed aerosol conditions in the case of air mass transports from the North Sea to southern Germany during early spring time.

[31] The large difference between the total and coarsemode AOT observed over Leipzig as well as over Munich on 16-17 April 2010 points to a strong contribution of freshly formed sulfate aerosol to the total optical thickness. During the next days the coarse-mode AOT was of the order of 0.03 to 0.05 and increased to values of $0.1-0.2$ on 19 20 April 2010 when the aged volcanic layers passed Germany for a second time. $70 \%-80 \%$ of the total AOT ranging from 0.4 to 0.85 over Leipzig on 19 April 2010 was, however, caused by fine-mode particles. Typical $500 \mathrm{~nm}$ AOT values are $0.25-0.3$ for westerly winds at Leipzig during springtime. Similar to the estimation of the typical AOT during nonvolcanic times at Munich, we analyzed all AERONET observations at Leipzig during April of the years 2007 to 2010, computed backward trajectories 


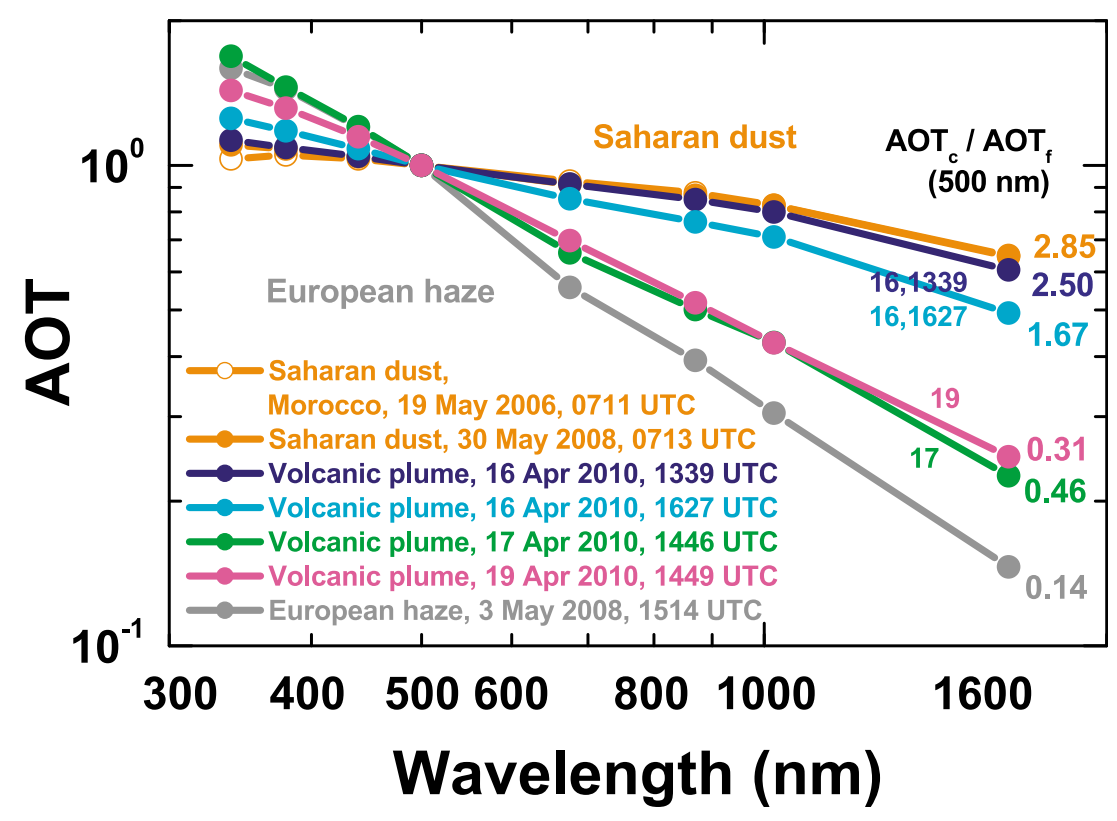

Figure 6. Spectral AOT from 340 to $1640 \mathrm{~nm}$ (normalized to unity at $500 \mathrm{~nm}$ ). The measurements of the 8-channel AERONET photometer at Leipzig on 16 (at 1339 and 1627 UTC), 17, and 19 April 2010 are compared with rather flat AOT spectra measured with the same photometer in southern Morocco in 2006 (open orange circles) and during a major Saharan dust outbreak over Leipzig in May 2008 (solid orange circles), and with a rather steep spectrum for almost pure European haze conditions. The given ratios of coarse-mode to fine-mode AOT describe the impact of the different particle modes on the AOT spectrum for the different cases.

( $850 \mathrm{hPa}$ level) for the 91 observations and selected cases that showed very similar trajectories to the ones for 19 April 2010. In this way, we found seven cases and assume that these cases represent typical aerosol conditions for air masses that come from the Atlantic, cross southern UK, northern France, Belgium, and western Germany, and finally arrive at Leipzig during April. The lidar observations on 19 April 2010 are discussed in section 4.3.

[32] A typical example of volcanic layering observed over Leipzig during the remaining volcanic period in April and May 2010 is discussed in section 4.4. The example case was measured on 21 April 2010. According to Figure 5, the coarse-mode AOT was low with values of $0.01-0.05$ on $21-$ 24 April 2010. Last major eruptions in mid-May 2010 mainly affected the EARLINET site of Cabauw. Coarsemode AOTs of up to 0.35 were recorded (see Figure 5). This case is presented in section 4.5.

[33] The time series of the Ångström exponents in Figure 5 (bottom) reflects the strong change in the bimodal volume size distribution of the volcanic particles on 16-17 April 2010. The rapid increase of the Ångström exponents indicates the strong decrease of the ash mass concentration and the increasing influence of fine-mode aerosol on the measured optical properties. The ash front which crossed Hamburg on 16 April 2010 showed 500/1020 nm Ångström exponents of about zero. Values of $0.3-0.5$ were observed over Leipzig 6-9 h later. Such low Ångström exponents are comparable to values found at Leipzig during a strong Saharan dust outbreak on 30 May 2008 (indicated as SAH in Figure 5) and reflect the presence of a large amount of large to giant ash particles [Ansmann et al., 2010]. Later on, the Ångström exponents were mostly >1 (except for cases with new ash plumes, as on 21 April 2010 and 17-18 May 2010).

[34] Figure 6 corroborates the interpretation of the Angström exponents. AOT observations with the 8-channel Leipzig AERONET photometer on 16, 17, and 19 April 2010 are shown. These volcanic AOT spectra are contrasted to two Saharan dust spectra. One was measured very close to the source region in southern Morocco [Müller et al., 2010] during the Saharan Mineral Dust Experiment SAMUM-1 [Heintzenberg, 2009] and the other was measured during the major Saharan dust event over Leipzig on 30 May 2008. Note that the two mineral dust spectra are undistinguishable for wavelengths $>500 \mathrm{~nm}$. This means that the size distributions of the Saharan dust particles were rather similar. Even after transport over $3000-5000 \mathrm{~km}$ the large dust particles were not significantly removed. The volcanic AOT spectrum measured over Leipzig at 1339 UTC on 16 April 2010 was similar to the Saharan dust AOT spectra. It can be concluded that, similarly to the Saharan dust transport, the coarse-mode fraction (ash particle fraction) was weakly affected by sedimentation processes during the $36 \mathrm{~h}$ travel to Leipzig. A size distribution is not available in the AERONET database for the 1339 UTC observations. First reliable sky radiance measurements, required in the AERONET retrieval, were not possible before 1627 UTC. At that time the densest ash plumes were already to the south of Leipzig.

[35] On 17 April 2010, the coarse-mode AOT decreased to values around $0.03-0.05$ at Leipzig. The AOT spectrum became similar to the one for urban haze, i.e., to the gray line in Figure 6 which represents the AOT spectrum for an European haze day that is dominated by the presence of 


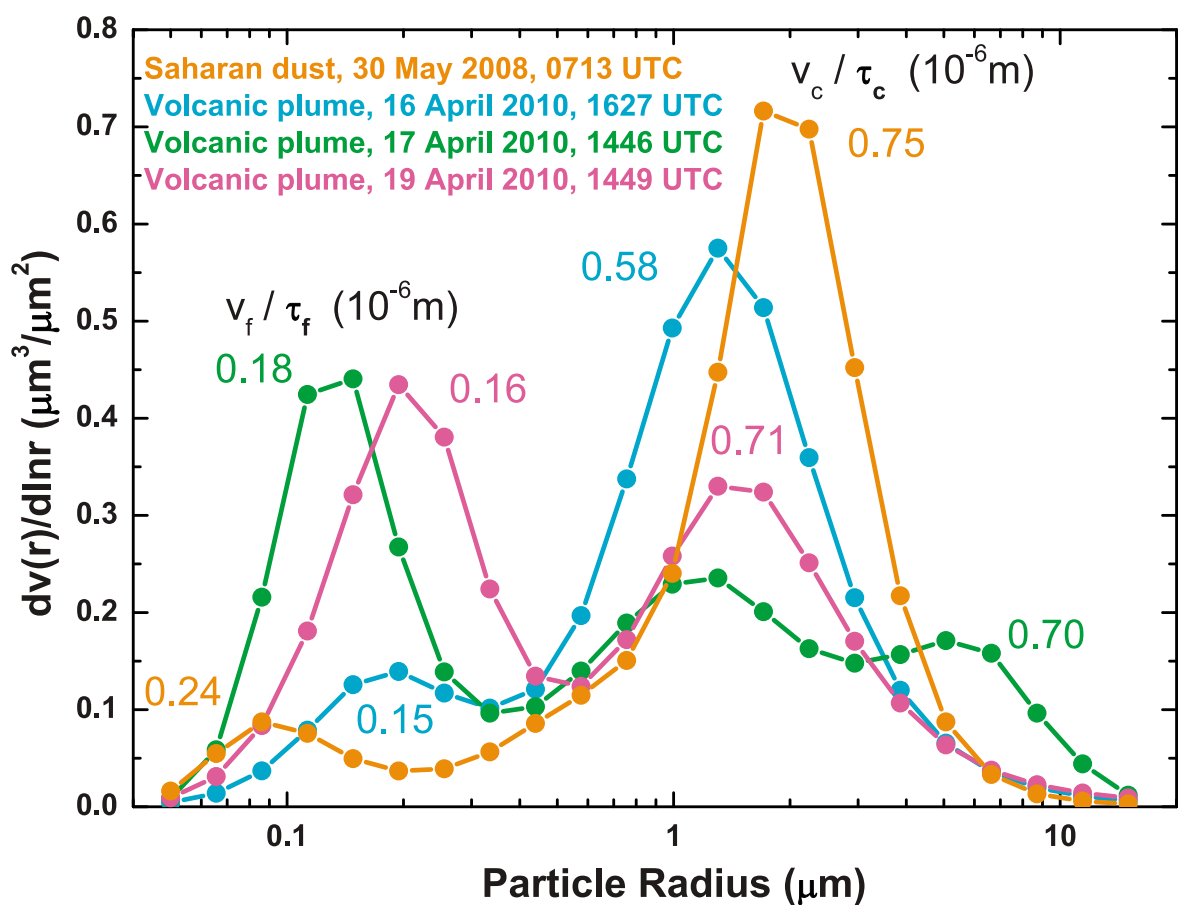

Figure 7. Column-integrated particle volume concentration $v\left(r_{n}, r_{n+1}\right)$ (normalized to the respective total volume concentration $v$ ) as measured with the Leipzig AERONET Sun photometer on 16, 17, and 19 April 2010. Values of $v\left(r_{n}, r_{n+1}\right)$ for 22 logarithmically equidistant bins in the radius range from $r_{1}=$ $0.05 \mu \mathrm{m}$ to $r_{23}=15 \mu \mathrm{m}$ are shown. For comparison, the particle size distribution measured during the Saharan dust event over Leipzig in May 2008 is shown (orange line). Values for $v_{\mathrm{f}} / \tau_{\mathrm{f}}$ and $v_{\mathrm{c}} / \tau_{\mathrm{c}}$ after the Dubovik method (532 $\mathrm{nm})$ are given as numbers.

sulfate particles. The AOT wavelength dependence for the short wavelength range was weaker on 19 April 2010 (the day with the 4.5 day old volcanic aerosol layers) compared to the one observed on 17 April 2010. On 19 April 2010, the AOT spectrum was obviously controlled by aged fine-mode particles (and the remaining ash load).

[36] Figure 7 presents volume size distributions that correspond to four cases in Figure 6. All shown volcanic size distributions measured at Leipzig from 16 to 19 April 2010 show a clear bimodal shape with effective radii of the coarse mode of $1.23 \mu \mathrm{m}$ (16 April 2010) to $1.45 \mu \mathrm{m}$ (17 and 19 April 2010). Figure 8 compares size distributions measured at Leipzig on 16 April 2010 with ones observed at Hamburg (16 April 2010, 0639 UTC), Munich (17 April 2010, 0732 UTC), and Cabauw (18 May 2010, 0715 UTC). At Hamburg, the volume size distribution was dominated by large ash particles. The formation of fine-mode sulfate aerosol is documented in the change of the size distribution from Hamburg over Leipzig to Munich on 16-17 April 2010. The size distribution over Cabauw on 18 May 2010 is similar to the one observed at Leipzig on 16 April 2010. The coarsemode effective radii $r_{\text {eff }}$ are $1.65 \mu \mathrm{m}$ (Munich), $1.40 \mu \mathrm{m}$ (Hamburg), and $1.29 \mu \mathrm{m}$ (Cabauw).

[37] Regarding the conversion factors (volume-to-AOT ratios) required in the mass retrieval, a continuation of the discussion in section 3.2 is necessary. Because of the narrow range of obtained effective radii from 1.23 to $1.65 \mu \mathrm{m}$ for the coarse mode the question arises, whether the size distributions shown in Figures 7 and 8 are trustworthy or not. During
SAMUM-1 in southern Morocco, an extensive closure study based on in situ observations of the size distribution aboard the research aircraft FALCON of DLR (Deutsches Zentrum für Luft- und Raumfahrt), multiwavelength Raman lidar, and Sun photometer measurements were performed [Müller et al., 2010]. The main result was that the effective radius of the coarse-mode particles as derived with the AERONET inversion scheme (considering particles with radii $<15 \mu \mathrm{m}$ ) was underestimated by a factor 2 or even more. For the Saharan dust cases in Figure 6 the coarse-mode effective radii are $1.62 \mu \mathrm{m}$ (southern Morocco, 19 May 2006) and $1.57 \mu \mathrm{m}$ (Leipzig, 30 May 2008). The FALCON in situ measurements in the well-mixed Saharan dust layer over the SAMUM field site on 19 May 2006 revealed effective radii of 3.3-4.3 $\mu \mathrm{m}$ for the coarse mode [Müller et al., 2010]. Because the AOT spectrum measured at Leipzig at 1339 UTC on 16 April 2010 is rather similar to the ones of Saharan dust, the corresponding coarse-mode effective radius may have been as large as $2-3 \mu \mathrm{m}$. A similar or even larger underestimation of the effective radius probably holds for the measurement at Hamburg in the early morning of 16 April 2010. Rose et al. [2001] found effective radii mostly from 2 to $5 \mu \mathrm{m}$ in volcanic clouds even 2-4 days after the eruptions of Mount Spurr, Alaska, in August and September 1992.

[38] As a consequence, the lidar data conversion of ash backscatter into ash mass concentrations (based on Figure 2) may lead to a considerable underestimation of the ash mass concentration in cases of fresh volcanic plumes. As discussed by Schumann et al. [2011] and Gasteiger et al. 


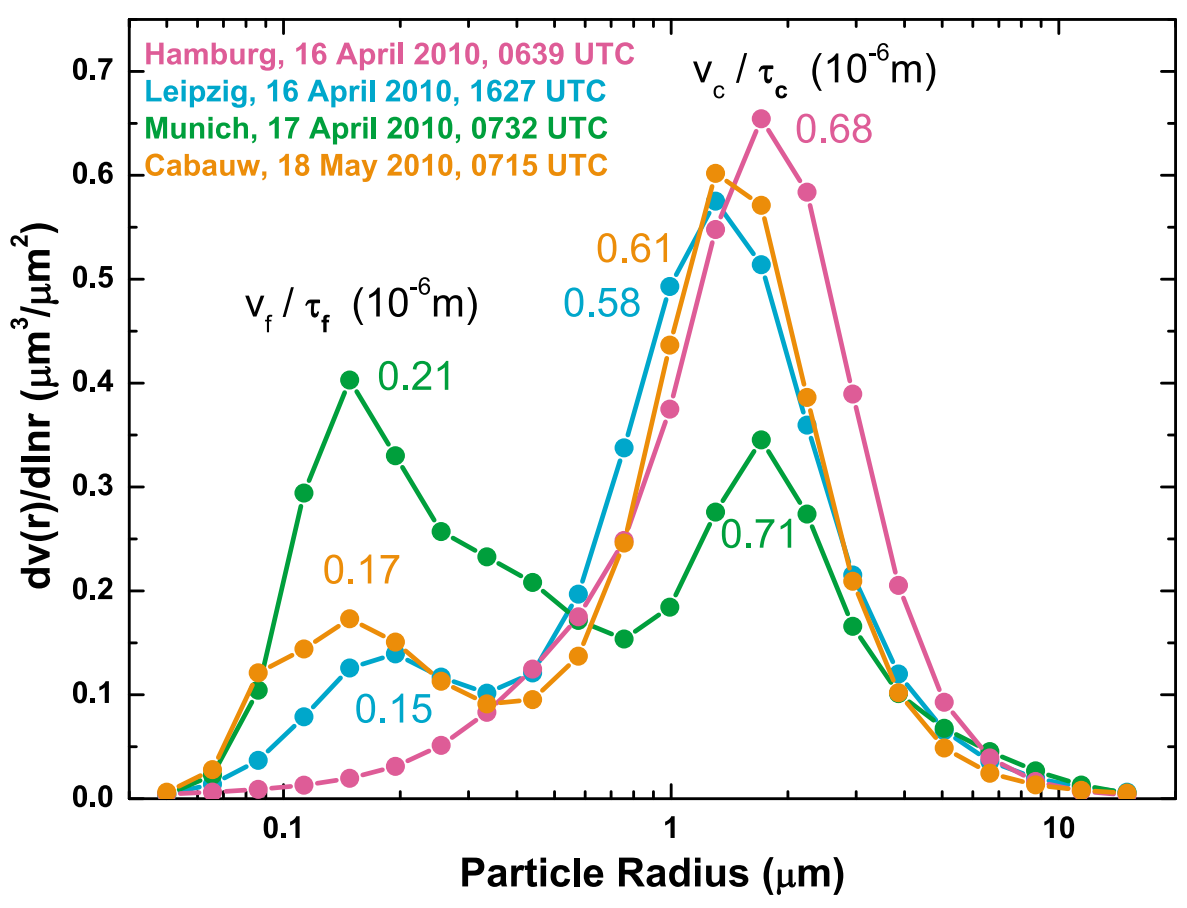

Figure 8. Normalized particle volume size distributions as measured with AERONET photometers at Hamburg, Leipzig, and Munich on 16-17 April 2010 and at Cabauw on 18 May 2010. Values for $v_{\mathrm{f}} / \tau_{\mathrm{f}}$ and $v_{\mathrm{c}} / \tau_{\mathrm{c}}$ after the Dubovik method are given as numbers.

[2011] the ash-related $v_{\mathrm{c}} / \tau_{\mathrm{c}}$ ratio is an almost linear function of effective radius for size distributions dominated by large to giant particles. In the geometric optics regime with an effective extinction efficiency of the particles of around two, the volume-to-AOT ratio is given by $2 r_{\text {eff }} / 3$. Then the volume-to-extinction ratio $\overline{v_{\mathrm{c}} / \tau_{\mathrm{c}}}$ is $2-3 \times 10^{-6} \mathrm{~m}$ for coarsemode effective radii of $3-4 \mu \mathrm{m}$ instead of $0.6 \times 10^{-6} \mathrm{~m}$ (Table 1). This results in volume-to-extinction ratios for the estimation of ash mass concentrations that are a factor of 35 larger than the ones used in this paper.

[39] On the other hand, Schumann et al. [2011] show that particles with radii $>15 \mu \mathrm{m}$ should have been completely removed from the volcanic ash plumes after $48 \mathrm{~h}$, if only sedimentation plays a role (no upward motions caused by light absorption in the volcanic layers, no convectively driven upward transport of ash in the boundary layer and free troposphere, no particle charging effects [Ulanowski et al., 2007; Harrison et al., 2010]). If sedimentation controls the ash particle size distribution, observations at Munich (17 April 2010, more than $50 \mathrm{~h}$ after the emission, Figure 3), Leipzig (19 April 2010, 104-110 h after the emission, section 4.3), and Cabauw (17 May 2010, 60-80 h after the emission, section 4.5) should have been not affected by the $15 \mu \mathrm{m}$ cutoff effect in the AERONET data analysis.

\subsection{Maximum Ash Load Over Hamburg on 16 April 2010}

[40] Figures 9-12 present profile observations of different phases in the evolution of the volcanic aerosol layers over central Europe in April and May 2010 in terms of total and ash backscatter coefficients and estimated sulfate and ash mass concentrations. The Hamburg observations during the period with the maximum $500 \mathrm{~nm}$ coarse-mode AOT of 1.01.2 are given in Figure 9. An almost pure ash layer was present from 2.0 to $5.75 \mathrm{~km}$ height. In the lofted ash plume maximum particle depolarization ratios were close to $34 \%$. Lidar ratios reached values of 50-55 $\mathrm{sr}$ in the centers of the three layers. AERONET fine-mode and coarse-mode $500 \mathrm{~nm}$ AOT values [after O'Neill et al., 2003] at 0635 UTC were 0.2 and 1.1 , respectively, so that the fine-mode fraction was about $15 \%$. The column-integrated backscatter coefficient (from $150 \mathrm{~m}$ to $5.75 \mathrm{~km}$ height, about $60 \mathrm{~min}$ before the AERONET observation) indicates a fine-mode-related backscatter fraction of $24 \%$.

[41] The $1 \mathrm{~h}$ mean ash mass concentration in Figure 9 reach peak values around $1000 \mu \mathrm{g} / \mathrm{m}^{3}$. The column ash load of the roughly $4 \mathrm{~km}$ deep plume was $1750 \mathrm{mg} / \mathrm{m}^{2}$. Due to the uncertainties in the volume-to-AOT conversion factors for fresh and dense aerosol plumes (due to the $15 \mu \mathrm{m}$ cutoff effect in the AERONET inversion), the ash mass concentrations may be underestimated by more than $100 \%$ as discussed above. Unfortunately, the ash concentrations in fresh ash layers are of great interest for aviation ash forecasts.

[42] In the lowermost $2000 \mathrm{~m}$ of the troposphere the particle depolarization ratio dropped to low values. This indicates the presence of volcanic and anthropogenic sulfate particles. The fine-fraction mass concentration ranged from 30 to $70 \mu \mathrm{g} / \mathrm{m}^{3}$ in this layer.

[43] The volcanic plumes reached Leipzig about 6-9 h later after they had passed Hamburg [Ansmann et al., 2010]. 


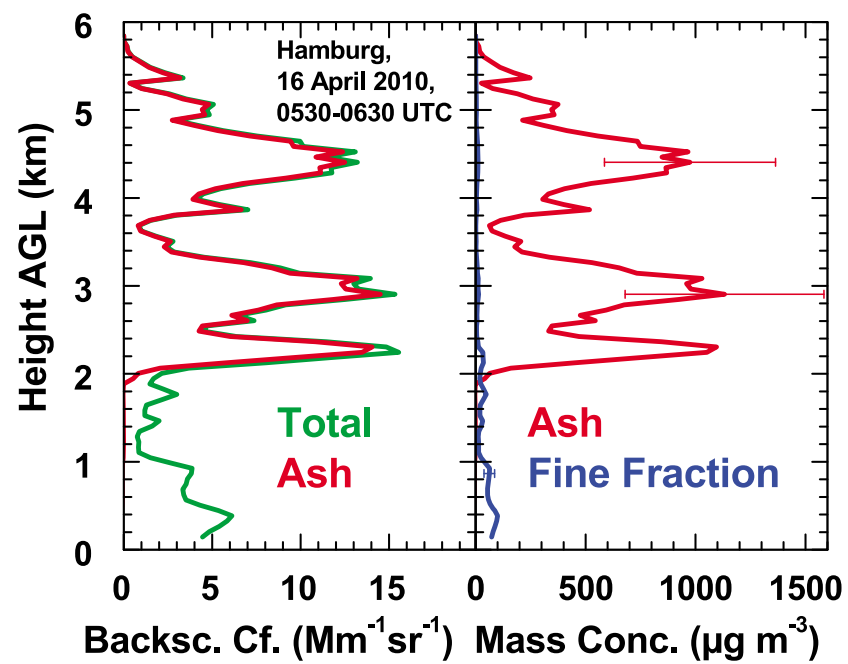

Figure 9. One hour mean values of (left) total particle and ash-related backscatter coefficients and (right) corresponding fine-mode and ash mass concentrations derived from lidar observations at Hamburg on 16 April 2010, 0530 0630 UTC. Error bars show the $40 \%$ uncertainty in the mass retrieval.

As mentioned, the maximum coarse-mode $500 \mathrm{~nm}$ AOT was 0.7 on 16 April 2010. Peak values of $1 \mathrm{~h}$ mean mass concentrations still were of the order of $1000 \mu \mathrm{g} / \mathrm{m}^{3}$. The maximum ash load was about $1000-1200 \mathrm{mg} / \mathrm{m}^{2}$. As for Hamburg, the underestimation of the maximum ash load may be considerable due to the $15 \mu \mathrm{m}$ cutoff effect in the AERONET retrieval.

\subsection{Fine Particle and Ash Layers Over Leipzig on 19 April 2010}

[44] Figure 10a shows the aerosol conditions over Leipzig on 19 April 2010. Aged volcanic layers passed the lidar site for a second time, more than $100 \mathrm{~h}$ after the emission. The color plot together with the depolarization ratio time series indicates two ash-containing layers: one below $3 \mathrm{~km}$ height with base height at about $1300 \mathrm{~m}$, just above the convective boundary layer $(\mathrm{BL})$ and another one in the free troposphere from 3.5 to $6 \mathrm{~km}$ height. According to 1200 UTC radiosonde profiles of temperature and humidity (observed at Lindenberg, $180 \mathrm{~km}$ northeast of Leipzig), a shallow BL with top height around $1200 \mathrm{~m}$ developed on 19 April 2010. Cumulus cloud formation between 1000 and $1300 \mathrm{~m}$ during the period from 1040 to 1350 UTC (see Figure 10a) indicates the BL top height. The advection of aged volcanic aerosol layers toward Leipzig within a southwesterly airflow began in the late evening of 18 April 2010 and lasted until the afternoon of 20 April 2010. Several altocumulus fields developed at the top of the aged volcanic layer at $3 \mathrm{~km}$ height after 1630 UTC. A cirrus layer developed at heights above $8 \mathrm{~km}$ after 1500 UTC. Virga of falling ice crystals are detected above $6 \mathrm{~km}$ later on.

[45] In the lower aerosol layer (1-3 km), weakly depolarizing fine-mode aerosol particles considerably contributed to the observed total backscatter coefficient (Figure 10b). The AERONET photometer measured fine-mode and coarse-mode $500 \mathrm{~nm}$ AOT of 0.51 and 0.15 , respectively, at 1449 UTC and thus a fine-mode fraction of $77 \%$. Based on the lidar data (from 0.5 to $6 \mathrm{~km}$ height, $1430-1530$ UTC) we obtain a non-ash backscatter fraction of $76 \%$ (Figure 10c). The lidar-derived $532 \mathrm{~nm}$ AOT agrees with the AERONET measurement (0.66) when a lidar ratio of 55-60 sr is applied to the backscatter coefficient profile and constant backscattering is assumed in the lowermost $500 \mathrm{~m}$. For the lowermost $500 \mathrm{~m}$, accurate backscatter coefficients cannot be derived from the lidar observations because of high uncertainties in the correction of the so-called overlap effect. This effect describes the incomplete laser beam receiver-field-of-view overlap in the near range of the lidar [Wandinger and Ansmann, 2002].

[46] This excellent agreement between the photometer and lidar observations demonstrates that our basic hypothesis (presented in sections 3.1 and 3.2) of externally mixed sulfate and ash particles is valid. Otherwise, such an accurate separation of the ash (coarse-mode) from the non-ash (finemode) particle fraction would be impossible. We can thus conclude that the contamination of the ash particles with sulfate was small and the respective uncertainty in the estimation of the ash mass concentration of minor importance.

[47] The continuous AERONET monitoring revealed an increase in AOT from 0.63 (0.60 fine-mode AOT, 1009 UTC) to 0.85 ( 0.75 fine-mode AOT, 1614 UTC). The finefraction mass concentration in the lower volcanic layer increased from values around $50 \mu \mathrm{g} / \mathrm{m}^{3}$ in the morning to values of almost $100 \mu \mathrm{g} / \mathrm{m}^{3}$ at around $2 \mathrm{~km}$ height in the late afternoon. As mentioned in section 4.1, typical springtime $500 \mathrm{~nm}$ AOT values are in the range of $0.25-0.3$ for westerly flows, when the aerosol (mainly sulfate) originates from the industrial centers in western Germany and western/ central Europe. Thus about $50 \%$ of the fine-mode optical depth on 19 April 2010 probably resulted from the volcanic event.

[48] The observations on 19 April 2010 show a sudden increase of the lidar-derived ash-related $532 \mathrm{~nm}$ AOT in the lower layer from 0.01 at $1000-1100$ UTC to values of $0.11-$ 0.15 around $1300-1500 \mathrm{UTC}$. In the layer from 4 to $6 \mathrm{~km}$ height, the lidar-derived ash-related AOT ranged from 0.02

Figure 10. (a) Height-time display of the $1064 \mathrm{~nm}$ range-corrected signal measured at Leipzig on 19 April 2010 (strong signals in red, weak signals in blue) and $1 \mathrm{~h}$ mean profiles of (b) particle depolarization ratio (time intervals in UTC are given at the top), (c) total and ash particle backscatter coefficient, and (d) fine-fraction and ash mass concentrations determined from the backscatter coefficients after cloud screening. A dense volcanic layer (red in Figure 10a) is located just above the boundary layer (which is topped by shallow cumulus clouds at heights from 1000 to $1250 \mathrm{~m}$ between 1040 and 1350 UTC). The top of this volcanic layer (advected from southwest) increased from 2.4 to $3.0 \mathrm{~km}$ between 1000 and 1700 UTC. Another volcanic layer (yellow) occurred in the free troposphere from 4 to $6 \mathrm{~km}$. Cirrus with virga was observed above $6 \mathrm{~km}$ height (after 1500 UTC). 

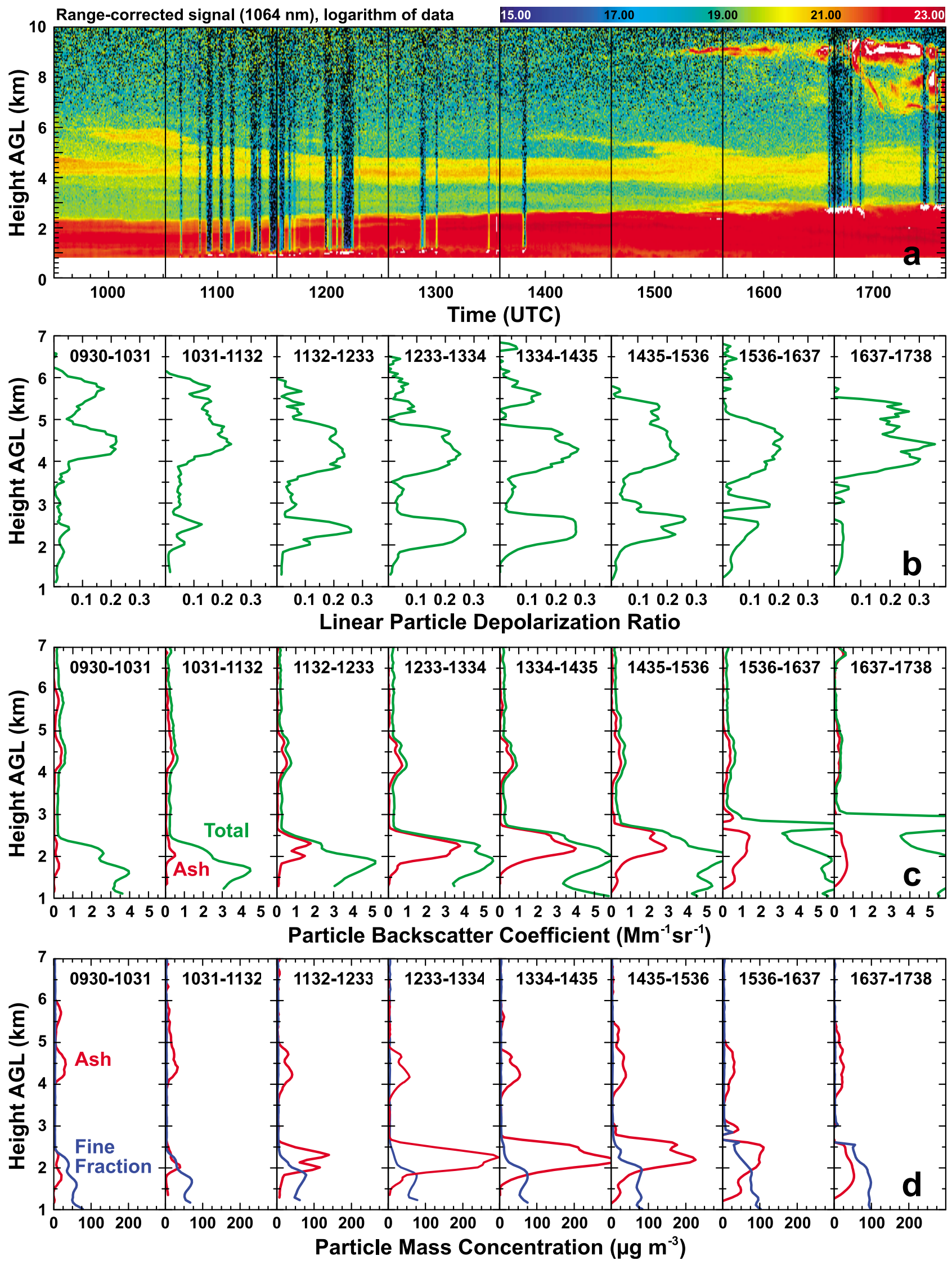

Figure 10 


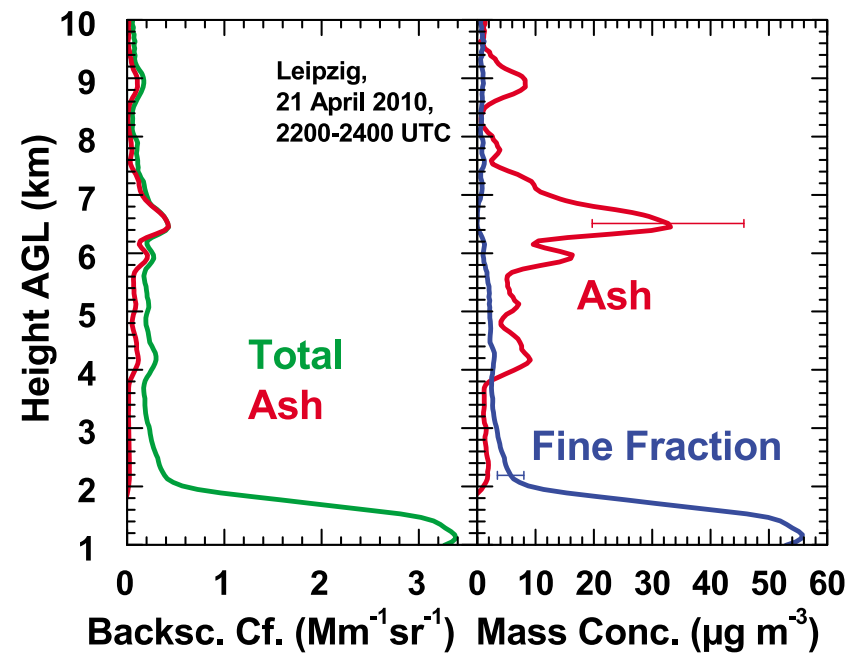

Figure 11. Same as Figure 9 except for the lidar observation at Leipzig on 21 April 2010, 2200-2400 UTC.

to 0.03 throughout the day. AERONET observations of the coarse-mode AOT are in agreement with these lidar findings.

[49] Figure 10d shows ash mass concentrations of up to $50 \mu \mathrm{g} / \mathrm{m}^{3}$ in the free tropospheric layer and peak values of up to $310 \mu \mathrm{g} / \mathrm{m}^{3}$ in the lower layer from 2 to $2.5 \mathrm{~km}(1230$ 1430 UTC). The DLR FALCON aircraft performed detailed profile measurements over Leipzig and Munich on this day [Schumann et al., 2011]. The observations over Leipzig lasted from 1451-1528 UTC and covered the height range from 2 to $9 \mathrm{~km}$ height. From the FALCON size distribution measurements, ash mass concentrations in the range of 10 $50 \mu \mathrm{g} / \mathrm{m}^{3}$ (on average, about $20-30 \mu \mathrm{g} / \mathrm{m}^{3}$ from 4 to $4.5 \mathrm{~km}$ height), and values from 60 to $160 \mu \mathrm{g} / \mathrm{m}^{3}$ in the lower layer from 2 to $3 \mathrm{~km}$ height were derived. The lidar observations (1 h mean values, 1435-1536 UTC) revealed ash mass concentrations of about $150-200 \mu \mathrm{g} / \mathrm{m}^{3}$ in the lower layer from 2 to $3 \mathrm{~km}$ height and a mean value of $35 \mu \mathrm{g} / \mathrm{m}^{3}$ in the layer from 4 to $4.5 \mathrm{~km}$ height. The agreement between the different observations is good in view of the horizontal inhomogeneity and temporal variability in the particle characteristics on this day and the uncertainties in both the in situ and in the remote sensing retrieval.

[50] By comparing the photometer-derived coarse-mode peak AOT of 0.7 on 16 April 2010 with the coarse-mode peak AOT of 0.15 of the aged layers on 19 April 2010, we find a decrease by a factor of 4-5 in the ash-related AOT within $72 \mathrm{~h}$. When comparing the ash load of $1000-1200 \mathrm{mg} / \mathrm{m}^{2}$ on 16 April 2010 with the value of $190-230 \mathrm{mg} / \mathrm{m}^{2}$ in the early afternoon of 19 April 2010, the decrease is also in the range of a factor of 5 within the 3 day period.

[51] It is worthwhile to mention that the in situ observations (FALCON) of the size distribution revealed an effective radius of $0.75 \mu \mathrm{m}$ for the mixture of fine- and coarse-mode particles in the free tropospheric ash-dominated layer (4$4.5 \mathrm{~km}$ height). This finding is roughly consistent with the AERONET value of $1.45 \mu \mathrm{m}$ for the coarse mode fraction (alone) of the observed tropospheric aerosol column. The effective radius of the vertical column for the entire size spectrum retrieved from the AERONET data was $0.32 \mu \mathrm{m}$ on 19 April 2010 at 1449 UTC. After 4.5 days, the large par- ticles with radii $>10 \mu \mathrm{m}$ appear to be removed completely, and the AERONET retrieval scheme covers the entire particle size distribution. Consequently, the ash mass concentrations in Figure 10 are considered as reliable.

\subsection{Minor Volcanic Event on 21 April 2010}

[52] The volcanic episode that began on 16 April 2010 ended on 20 April 2010. Fresh volcanic aerosol originating from eruptions on 17-19 April 2010 [Stohl et al., 2011] reached central Europe on 21 April 2010 and on the following days. Distinct layers up to $10 \mathrm{~km}$ height were detected with the lidars. No significant change in the geometrical depths and heights of the layers was observed within several hours of lidar measurements. Figure 11 provides an impression of this layering. Although many structures are visible, the free tropospheric AOT was typically low. The lidar-derived ashrelated $532 \mathrm{~nm}$ AOT above $2 \mathrm{~km}$ height was 0.04 on 21 April 2010. The total AOT was about 0.08-0.09 (2-10 km height range). On 22 April 2010 the lidar-derived ash AOT in the free troposphere decreased to values of 0.01 at $532 \mathrm{~nm}$.

[53] Peak ash mass concentrations in Figure 11 are estimated to be close to $30 \mu \mathrm{g} / \mathrm{m}^{3}$. The ash mass load was $50 \mathrm{mg} / \mathrm{m}^{2}$ for the free tropopsphere from 2 to $10 \mathrm{~km}$ height. The last distinct aerosol layers of volcanic origin were observed over Leipzig on 26 May 2010. The volcanic episode thus covered a period of almost six weeks.

\subsection{Final Major Ash Plumes Over Cabauw on 17 May 2010}

[54] A final phase with dense ash plumes occurred on 17 18 May 2010. Figure 4d shows an extended area with high AOT over the North Sea on 17 May 2010. These volcanic aerosol layers mainly affected western Europe during the following days. Figure 12 presents the measurement over Cabauw in the evening of 17 May 2010. The layers passed Cabauw about 60-80 h after the emission [Schumann et al., 2011]. The lidar-derived $532 \mathrm{~nm}$ AOT was 0.53 (height range up to $6 \mathrm{~km}$ ) with an ash contribution of $0.3-0.35$. The AERONET-derived total and coarse-mode AOTs were 0.48 and 0.31 , respectively, at 1800 UTC (last observation on this

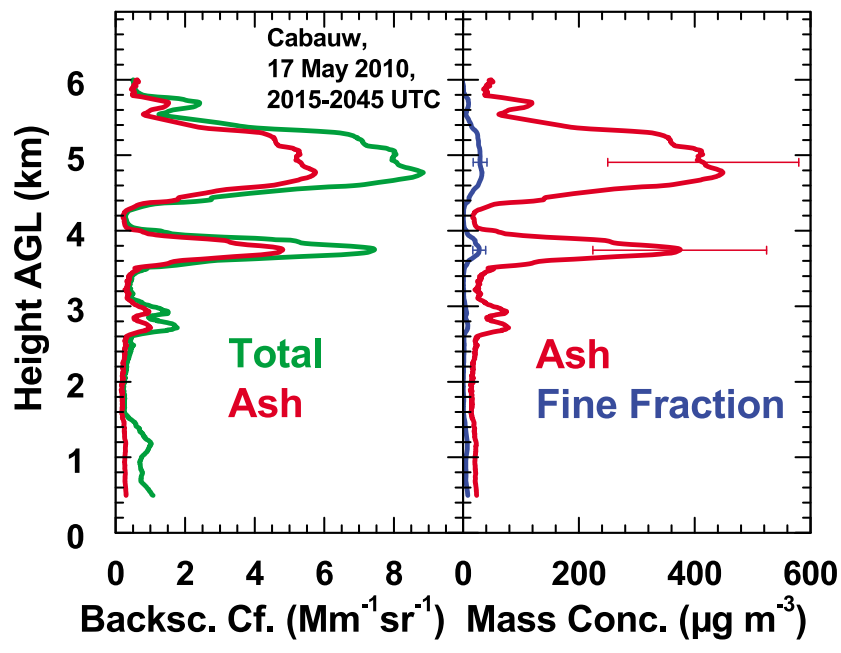

Figure 12. Same as Figure 9 except for the lidar observation at Cabauw on 17 May 2010, 2015-2045 UTC. 
day). Compared to the mid-April episode, a much higher contribution of weakly depolarizing fine-mode particles (37\% contribution to the total particle backscatter coefficient) was observed in the ash-dominated free tropospheric layers. AERONET data support this finding of high finemode AOT contribution. At 1800 UTC the AERONET finemode AOT fraction was $35 \%$. This excellent agreement between the photometer and lidar findings again corroborates that fine-mode (sulfate) and coarse-mode (ash) particles are widely externally mixed. A significant contamination of the ash particles with sulfate is not obvious from the lidar measurements.

[55] The ash mass concentration again reached high values of about $400 \mu \mathrm{g} / \mathrm{m}^{3}$ in several layers from 2 to $6 \mathrm{~km}$ height. The 2-6 km ash mass load was about $550 \mathrm{mg} / \mathrm{m}^{2}$. The DLR FALCON performed extended observations over the North Sea, including one in the afternoon of 17 May 2010 about $100 \mathrm{~km}$ northwest of Cabauw [Schumann et al., 2011]. The in situ observations (1541-1632 UTC) revealed ash mass concentrations mostly in the range of $150-400 \mu \mathrm{g} / \mathrm{m}^{3}$ with peak values of $550 \mu \mathrm{g} / \mathrm{m}^{3}$ at heights from 4 to $6 \mathrm{~km}$. Again the agreement between the remote and in situ measurements is good in view of the different sites and inhomogeneities in the volcanic aerosol fields (see Figure 4d).

\section{Summary}

[56] A method that allows us to separate the fine-fraction and ash-related optical properties based on polarization lidar and Sun photometer observations was presented. The method can be used to derive the mass concentrations of highly light-depolarizing ash and weakly depolarizing nonash or fine-mode particles. It was applied to central European EARLINET observations after the eruptions of the Eyjafjallajökull volcano in April and May 2010. Different stages in the evolution of the volcanic aerosol layers over central Europe in April and May 2010 were characterized in terms of vertically resolved optical properties, fine-mode and ash particle mass concentrations, and layer-integrated mass loads.

[57] As a source for high uncertainties in the ash mass retrieval, the restriction of the AERONET data inversion scheme to particle radii $<15 \mu \mathrm{m}$ was identified. In case of the presence of a considerable amount of large to giant particles (in fresh volcanic plumes), a reliable conversion of the measured optical properties into mass concentrations is not possible with the conversion factors derived from the volume concentrations and AOT values provided by the AERONET database. Nevertheless, a high level of consistency between the basic AERONET observations of fine-mode and coarse-mode AOTs and respective basic polarization lidar observations of non-ash and ash backscatter profiles corroborates that the new method is a powerful tool to obtain detailed information of mixed volcanic aerosol layers.

[58] Maximum coarse-mode $500 \mathrm{~nm}$ AOTs were of the order of 1.0-1.2. Maximum ash concentrations and column mass loads reached values around $1500 \mu \mathrm{g} / \mathrm{m}^{3}$ and $1750 \mathrm{mg} / \mathrm{m}^{2}$, respectively, on $16-17$ April 2010 . The Leipzig observations on 16 and 19 April 2010 revealed that the ash load decreased by a factor of about 5 within $72 \mathrm{~h}$. A strong contribution of volcanic sulfate particles to the overall fine- mode AOT was observed. On 19 April 2010 the fine-mode AOT was higher by $0.3-0.5$ compared to the long-term AERONET mean value for westerly flows in the spring season. The different eruptive phases compared (14-15 April 2010, 17-19 April 2010, mid-May 2010) were characterized by clear differences in the aerosol optical properties, mass loadings, and aerosol vertical structures.

[59] Acknowledgments. We are grateful to the AERONET team headed by Brent Holben for their service (Sun photometer calibration, data analysis, quality assurance) and that the Sun photometers at Cabauw, Hamburg, Leipzig, and Munich performed well and measured almost around the clock during the Eyjafjallajökull volcanic period in 2010. The financial support for EARLINET by the European Commission under grant RICA-025991 is gratefully acknowledged. The authors also acknowledge ESA financial support under ESTEC contract 21487/08/NL/HE.

\section{References}

Ackermann, J. (1998), The extinction-to-backscatter ratio of tropospheric aerosol: A numerical study, J. Atmos. Oceanic Technol., 15, 1043-1050, doi:10.1175/1520-0426(1998)015<1043:TETBRO>2.0.CO;2.

Ansmann, A., U. Wandinger, M. Riebesell, C. Weitkamp, and W. Michaelis (1992), Independent measurement of extinction and backscatter profiles in cirrus clouds by using a combined Raman elastic-backscatter lidar, Appl. Opt., 31, 7113-7131, doi:10.1364/AO.31.007113.

Ansmann, A., et al. (2010), The 16 April 2010 major volcanic ash plume over central Europe: EARLINET lidar and AERONET photometer observations at Leipzig and Munich, Germany, Geophys. Res. Lett., 37, L13810, doi:10.1029/2010GL043809.

Apituley, A., K. M. Wilson, C. Potma, H. Volten, and M. de Graaf (2009), Performance assessment and application of Caeli-A highperformance Raman lidar for diurnal profiling of water vapour, aerosols, and clouds, paper presented at 8th International Symposium on Tropospheric Profiling, Delft, Netherlands, 18-23 Oct.

Barnaba, F., and G. P. Gobbi (2004), Aerosol seasonal variability over the Mediterranean region and relative impact of maritime, continental, and Saharan dust particles over the basin from MODIS data in the year 2001, Atmos. Chem. Phys., 4, 2367-2391, doi:10.5194/acp-4-2367-2004.

Dubovik, O., and M. King (2000), A flexible inversion algorithm for retrieval of aerosol optical properties from Sun and sky radiance measurements, J. Geophys. Res., 105, 20,673-20,696, doi:10.1029/ 2000JD900282.

Dubovik, O., et al. (2006), Application of spheroid models to account for aerosol particle nonsphericity in remote sensing of desert dust, J. Geophys. Res., 111, D11208, doi:10.1029/2005JD006619.

Durant, A. J., R. A. Shaw, W. I. Rose, Y. Mi, and G. G. J. Ernst (2008), Ice nucleation and overseeding of ice in volcanic clouds, J. Geophys. Res., 113, D09206, doi:10.1029/2007JD009064.

Fernald, F. G. (1984), Analysis of atmospheric lidar observations: Some comments, Appl. Opt., 23, 652-653, doi:10.1364/AO.23.000652.

Ferrare, R., S. Melfi, D. Whiteman, K. Evans, and R. Leifer (1998), Raman lidar measurements of aerosol extinction and backscattering: 1. Methods and comparisons, J. Geophys. Res., 103, 19,663-19,672, doi:10.1029/ 98JD01646.

Flentje, H., et al. (2010), The Eyjafjallajökull eruption in April 2010Detection of volcanic plume using in-situ measurements, ozone sondes, and lidar-ceilometer profiles, Atmos. Chem. Phys., 10, 10,085-10,092, doi:10.5194/acp-10-10085-2010.

Fornea, A. P., S. D. Brooks, J. B. Dooley, and A. Saha (2009), Heterogeneous freezing of ice on atmospheric aerosols containing ash, soot, and soil, J. Geophys. Res., 114, D13201, doi:10.1029/2009JD011958.

Freudenthaler, V., et al. (2009), Depolarization-ratio profiling at several wavelengths in pure Saharan dust during SAMUM 2006, Tellus, Ser. $B, 61,165-179$, doi:10.1111/j.1600-0889.2008.00396.x

Gasteiger, J., S. Groß, V. Freudenthaler, and M. Wiegner (2011), Volcanic ash from Iceland over Munich: Mass concentration retrieved from ground-based remote sensing measurements, Atmos. Chem. Phys., 11, 2209-2223, doi:10.5194/acp-11-2209-2011.

Graf, H.-F., J. Feichter, and B. Langmann (1997), Volcanic sulfur emissions: Estimates of source strength and its contribution to the global sulfate distribution, J. Geophys. Res., 102, 10,727-10,738, doi:10.1029/ 96JD03265.

Groß, S., J. Gasteiger, V. Freudenthaler, F. Schnell, and M. Wiegner (2010), Characterization of the Eyjafjallajökull ash-plume by means of 
lidar measurements over the Munich EARLINET site, Proc. SPIE, 7832, doi: $10.1117 / 12.869020$.

Groß, S., M. Tesche, V. Freudenthaler, C. Toledano, M. Wiegner, A. Ansmann, D. Althausen, and M. Seefeldner (2011), Characterization of Saharan dust, marine aerosols and a mixture of biomass burning aerosols and dust by means of multi-wavelength depolarization- and Raman lidar measurements during SAMUM-2, Tellus, Ser. B, in press.

Harrison, R. G., K. A. Nicoll, Z. Ulanowski, and T. A. Mather (2010), Selfcharging of the Eyjafjallajökull volcanic ash plume, Environ. Res. Lett. 5, 024004, doi:10.1088/1748-9326/5/2/024004.

Heinold, B., J. Helmert, O. Hellmuth, R. Wolke, A. Ansmann, B. Marticorena, B. Laurent, and I. Tegen (2007), Regional modeling of Saharan dust events using LM-MUSCAT: Model description and case studies, J. Geophys. Res., 112, D11204, doi:10.1029/2006JD007443.

Heinold, B., et al. (2008), Regional Saharan dust modeling during the SAMUM 2006 campaign, Tellus, Ser. B, 61, 307-324, doi:10.1111/ j.1600-0889.2008.00387.x.

Heinold, B., I. Tegen, R. Wolke, A. Ansmann, I. Mattis, A. Minikin, U. Schumann, and B. Weinzierl (2011), Simulations of the 2010 Eyjafjallajökull volcanic ash dispersal over Europe using COSMOMUSCAT, Atmos. Environ., doi:10.1016/j.atmosenv.2011.05.021, in press.

Heintzenberg, J. (2009), The SAMUM-1 experiment over southern Morocco: Overview and introduction, Tellus, Ser. B, 61, 2-11, doi:10.1111/j.1600-0889.2008.00403.x.

Hess, M., P. Koepke, and I. Schult (1998), Optical properties of aerosols and clouds: The software package OPAC, Bull. Am. Meteorol. Soc., 79, 831-844, doi:10.1175/1520-0477(1998)079<0831:OPOAAC $>2.0$. $\mathrm{CO} ; 2$.

Holben, B. N., et al. (1998), AERONET - A federated instrument network and data archive for aerosol characterization, Remote Sens. Environ., 66, 1-16, doi:10.1016/S0034-4257(98)00031-5.

Mattis, I., A. Ansmann, D. Müller, U. Wandinger, and D. Althausen (2004), Multiyear aerosol observations with dual-wavelength Raman lidar in the framework of EARLINET, J. Geophys. Res., 109, D13203, doi:10.1029/2004JD004600.

Mattis, I., et al. (2010), Volcanic aerosol layers observed with multiwavelength Raman lidar over central Europe in 2008-2009, J. Geophys. Res., 115, D00L04, doi:10.1029/2009JD013472.

Müller, D., et al. (2010), Mineral dust observed with AERONET Sun photometer, Raman lidar, and in situ instruments during SAMUM 2006 Shape-independent particle properties, J. Geophys. Res., 115, D07202, doi:10.1029/2009JD012520.

O’Neill, N. T., T. F. Eck, A. Smirnov, B. N. Holben, and S. Thulasiraman (2003), Spectral discrimination of coarse and fine mode optical depth, J. Geophys. Res., 108(D17), 4559, doi:10.1029/2002JD002975.

Pappalardo, G., et al. (2010), EARLINET correlative measurements for CALIPSO: First intercomparison results, J. Geophys. Res., 115, D00H19, doi:10.1029/2009JD012147.

Reichardt, J., A. Dörnbrack, S. Reichardt, P. Yang, and T. J. McGee (2004), Mountain wave PSC dynamics and microphysics from groundbased lidar measurements and meteorological modeling, Atmos. Chem. Phys., 4, 1149-1165, doi:10.5194/acp-4-1149-2004.

Rose, W. I., G. J. S. Bluth, D. J. Schneider, G. G. J. Ernst, C. M. Riley, L. J. Henderson, and R. G. McGimsey (2001), Observations of volcanic clouds in their first few days of atmospheric residence: The 1992 eruptions of Crater Peak, Mount Spurr Volcano, Alaska, J. Geol., 109, 677-694, doi:10.1086/323189.

Sassen, K. (2005), Polarization in lidar, Lidar: Range-Resolved Optical Remote Sensing of the Atmosphere, edited by C. Weitkamp, pp. 19-42, Springer, New York.

Schmid, B., et al. (2009), Validation of aerosol extinction and water vapor profiles from routine Atmospheric Radiation Measurement Program Climate Research Facility measurements, J. Geophys. Res., 114, D22207, doi:10.1029/2009JD012682.

Schumann, U., et al. (2011), Airborne observations of the Eyjafjalla volcano ash cloud over Europe during air space closure in April and May 2010, Atmos. Chem. Phys., 11, 2245-2279, doi:10.5194/acp-11-22452011 .
Shimizu, A., N. Sugimoto, I. Matsui, K. Arao, I. Uno, T. Murayama, N. Kagawa, K. Aoki, A. Uchiyama, and A. Yamazaki (2004), Continuous observations of Asian dust and other aerosols by polarization lidars in China and Japan during ACE-Asia, J. Geophys. Res., 109, D19S17, doi:10.1029/2002JD003253.

Spindler, G., E. Brüggemann, T. Gnauk, A Grüner, K. Müller, and H. Herrmann (2010), A four-year size-segregated characterization study of particles $\mathrm{PM}_{10}$ and $\mathrm{PM}_{2.5}$, and $\mathrm{PM}_{1}$ depending on air mass origin at Melpitz, Atmos. Environ., 44, 164-173, doi:10.1016/j.atmosenv. 2009.10.015.

Stohl, A., et al. (2011), Determination of time- and height-resolved volcanic ash emissions and their use for quantitative ash dispersion modelling: The 2010 Eyjafjallajökull eruption, Atmos. Chem. Phys., 11, 4333-4351, doi:10.5194/acp-11-4333-2011.

Sugimoto, N., I. Uno, M. Nishikawa, A. Shimizu, I. Matsui, X. Dong, Y. Chen, and H. Quan (2003), Record heavy Asian dust in Beijing in 2002: Observations and model analysis of recent events, Geophys. Res. Lett., 30(12), 1640, doi:10.1029/2002GL016349.

Tang, I., and H. Munkelwitz (1994), Water activities, densities, and refractive indices of aqueous sulfates and sodium nitrate droplets of atmospheric importance, J. Geophys. Res., 99, 18,801-18,808, doi:10.1029/ 94JD01345.

Tesche, M., A. Ansmann, D. Müller, D. Althausen, R. Engelmann, V. Freudenthaler, and S. Groß (2009), Separation of dust and smoke profiles over Cape Verde by using multiwavelength Raman and polarization lidars during SAMUM 2008, J. Geophys. Res., 114, D13202, doi:10.1029/2009JD011862.

Tesche, M., D. Müller, S. Groß, A. Ansmann, D. Althausen, V. Freudenthaler, B. Weinzierl, A. Veira, and A. Petzold (2011), Optical and microphyiscal properties of smoke over Cape Verde inferred from multiwavelength lidar measurements, Tellus, Ser. B, in press.

Toledano, C., M. Wiegner, M. Garhammer, M. Seefeldner, J. Gasteiger, D. Müller, and P. Köpke (2009), Spectral aerosol optical depth characterization of desert dust during SAMUM 2006, Tellus, Ser. B, 61, 216-228, doi:10.1111/j.1600-0889.2008.00382.x.

Ulanowski, Z., J. Bailey, P. W. Lucas, J. H. Hough, and E. Hirst (2007), Alignment of atmospheric mineral dust due to electric field, Atmos. Chem. Phys., 7, 6161-6173, doi:10.5194/acp-7-6161-2007.

Wandinger, U., and A. Ansmann (2002), Experimental determination of the lidar overlap profile with Raman lidar, Appl. Opt., 41, 511-514, doi:10.1364/AO.41.000511.

Wandinger, U., et al. (2004), Air mass modification over Europe: EARLINET aerosol observations from Wales to Belarus, J. Geophys. Res., 109, D24205, doi:10.1029/2004JD005142.

Wiegner, M., J. Gasteiger, S. Groß, F. Schnell, V. Freudenthaler, and R. Forkel (2011), Characterization of the Eyjafjallajökull ash-plume: Potential of lidar remote sensing, Phys. Chem. Earth, doi:10.1016/j. pce. 2011.01 .006 , in press.

A. Ansmann, A. Hiebsch, I. Mattis, J. Schmidt, P. Seifert, M. Tesche, and U. Wandinger, Leibniz Institute for Tropospheric Research, Permoserstrasse 15, D-04318 Leipzig, Germany. (albert@tropos.de; hiebsch@tropos.de; ina@tropos.de; joerg@tropos.de; seifert@tropos.de; tesche@tropos.de; ulla@tropos.de)

A. Apituley and K. M. Wilson, Royal Netherlands Meteorological Institute, Wilhelminalaan 10, NL-3732 GK De Bilt, Netherlands. (arnoud.apituley@kmni.nl; keith.wilson@kmni.nl)

V. Freudenthaler, S. Groß, F. Schnell, and M. Wiegner, Meteorological Institute, Ludwig-Maximilians-Universität, Theresienstrasse 37, D-80333 Munich, Germany. (volker.freudenthaler@physik.uni-muenchen.de; silke. gross@physik.uni-muenchen.de; franziska.schnell@physik.uni-muenchen. de; m.wiegner@physik.uni-muenchen.de)

B. Heinold, School of Earth and Environment, University of Leeds, Leeds LS2 9JT, UK. (B.Heinold@leeds.ac.uk)

H. Linné and I. Serikov, Max Planck Institute for Meteorology, Bundesstrasse 55, D-20146 Hamburg, Germany. (ilya.serikov@zmaw.de; holger.linne@zmaw.de) 